\title{
Measure Guideline: Ventilation Cooling
}

D. Springer, B. Dakin, and A. German Alliance for Residential Building Innovation (ARBI) 


\section{NOTICE}

This report was prepared as an account of work sponsored by an agency of the United States government. Neither the United States government nor any agency thereof, nor any of their employees, subcontractors, or affiliated partners makes any warranty, express or implied, or assumes any legal liability or responsibility for the accuracy, completeness, or usefulness of any information, apparatus, product, or process disclosed, or represents that its use would not infringe privately owned rights. Reference herein to any specific commercial product, process, or service by trade name, trademark, manufacturer, or otherwise does not necessarily constitute or imply its endorsement, recommendation, or favoring by the United States government or any agency thereof. The views and opinions of authors expressed herein do not necessarily state or reflect those of the United States government or any agency thereof.

Available electronically at http://www.osti.gov/bridge

Available for a processing fee to U.S. Department of Energy

and its contractors, in paper, from:

U.S. Department of Energy

Office of Scientific and Technical Information

P.O. Box 62

Oak Ridge, TN 37831-0062

phone: 865.576.8401

fax: 865.576.5728

email: mailto:reports@adonis.osti.gov

Available for sale to the public, in paper, from:

U.S. Department of Commerce

National Technical Information Service

5285 Port Royal Road

Springfield, VA 22161

phone: 800.553 .6847

fax: 703.605 .6900

email: orders@ntis.fedworld.gov

online ordering: http://www.ntis.gov/ordering.htm

Printed on paper containing at least $50 \%$ wastepaper, including $20 \%$ postconsumer waste 


\title{
Measure Guideline: Ventilation Cooling
}

\author{
Prepared for: \\ Building America \\ Building Technologies Program \\ Office of Energy Efficiency and Renewable Energy \\ U.S. Department of Energy \\ Prepared by: \\ D. Springer, B. Dakin, A. German \\ Alliance for Residential Building Innovation (ARBI) \\ Davis Energy Group, Team Lead \\ 123 C Street \\ Davis, California 95616 \\ NREL Technical Monitor: Michael Gestwick \\ Prepared under Subcontract No. KNDJ-0-40340-00
}

April 2012 
[This page left blank] 


\section{Contents}

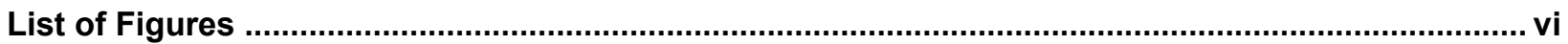

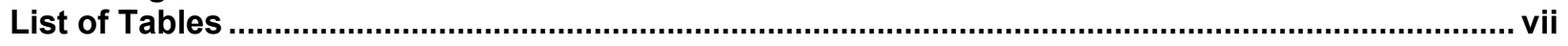

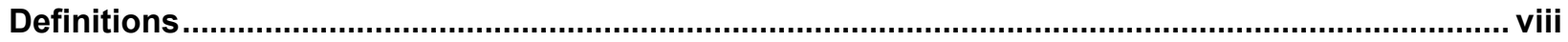

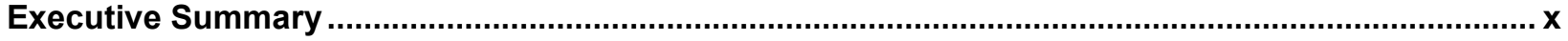

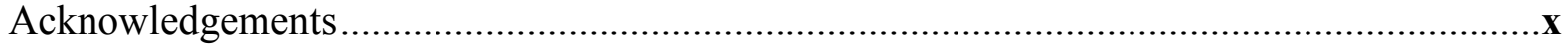

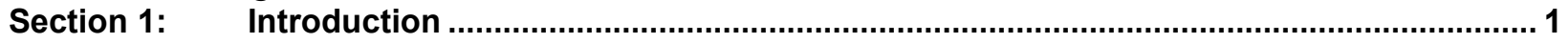

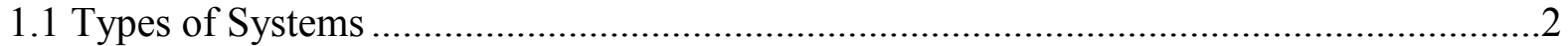

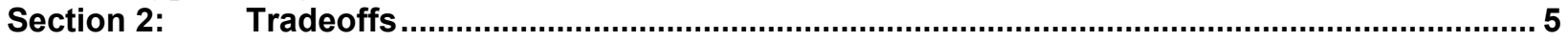

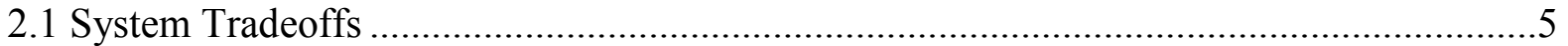

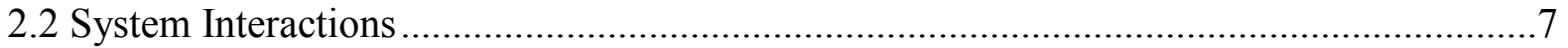

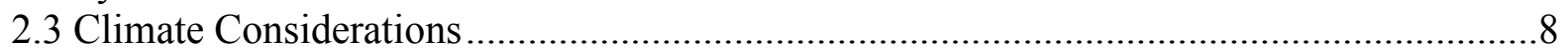

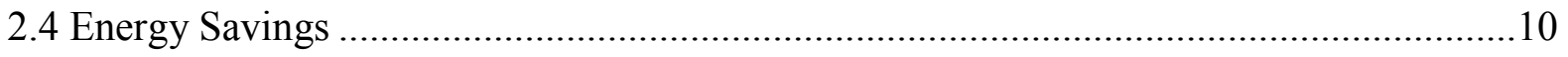

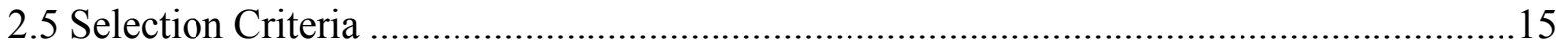

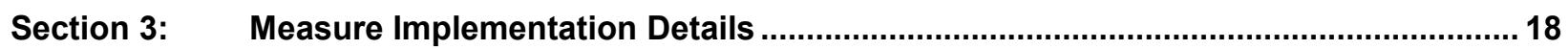

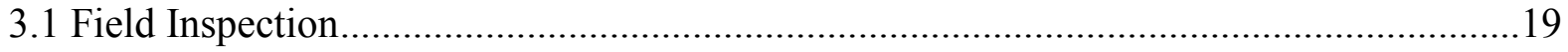

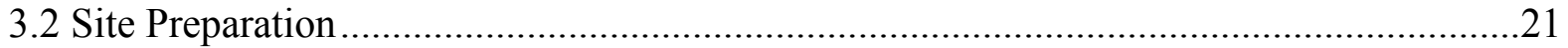

3.3 Installation Procedure - Whole House Fans .................................................................22

3.4 Operation and Maintenance - Whole House Fans......................................................24

3.5 Installation Procedures - Central Fan Systems.........................................................25

3.6 Operation and Maintenance - Central Fan Systems ...................................................30

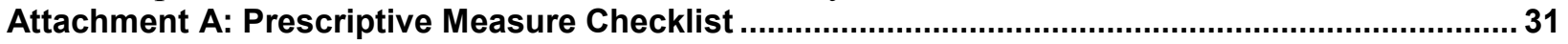

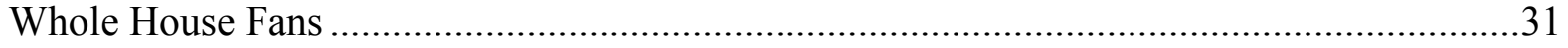

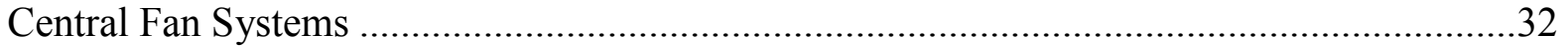

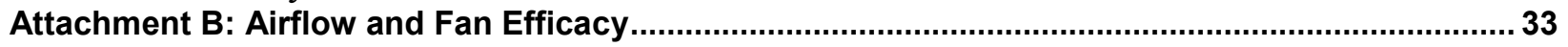

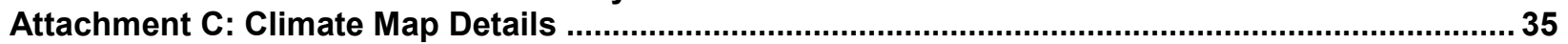

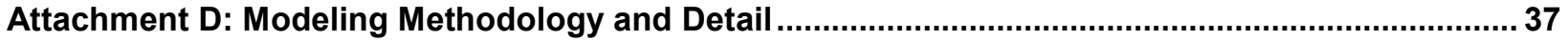

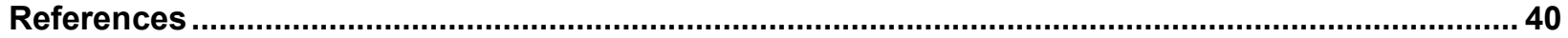




\section{List of Figures}

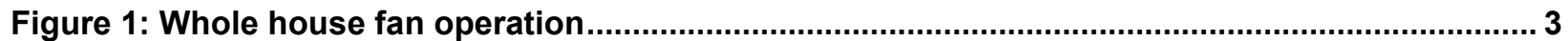

Figure 2: Central fan system operation in standard air conditioning mode ........................................ 4

Figure 3: Central fan system operation in ventilation cooling mode .................................................. 4

Figure 4: Favorable climates for ventilation cooling ................................................................ 9

Figure 5: Building America and IECC climate zone reference map .................................................. 11

Figure 6: Ventilation cooling system performance comparison and percent energy savings for

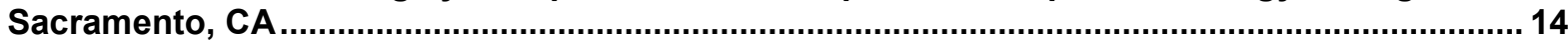

Figure 7: Cooling energy use vs. maximum airflow for an $1,860 \mathrm{ft}^{2}$ house in a hot-dry climate ...... 17

Figure 8: Diagram of safety check process for whole house fan .................................................... 20

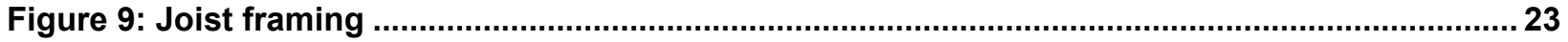

Figure 10: Outside air damper position relative to operational mode ......................................... 25

Figure 11: For this house the upper set of louvers is for the outside air intake; the lower pair is for

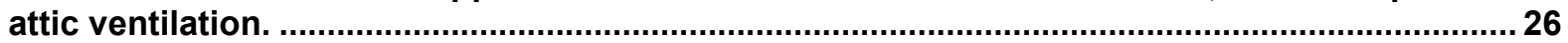

Figure 12: Multiple return air path configurations ........................................................................ 28

Figure 13: Typical airflow and fan power relationship for whole house fans..................................33

Figure 14: Fan efficacy vs. airflow for ECM fan in typical $2000 \mathrm{cfm}$ central system ........................ 34

Figure 15: Comparison of mean temperature swing and mean minimum temperature ................... 36

Figure 16: Comparison of mean temperature swing, mean minimum temperature, and relative

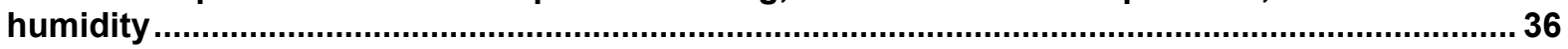

Unless otherwise noted, all figures were created by the ARBI team. 


\section{List of Tables}

Table 1: Tradeoffs Between Ventilation Cooling System Types .................................................... 5

Table 2: Estimated Energy Savings for Whole House Fans ............................................................ 12

Table 3: Estimated Energy Savings for Variable Speed Central Fan Ventilation Cooling Systems. 13

Table 4: Estimated Energy Savings for Fixed Speed Central Fan Ventilation Cooling Systems ..... 13

Table 5: Santa Rosa Cooling Strategy Energy Use and Hours Above Indoor Thermostat Setpoint 14

Table 6: Required Fan Capacities for Desired Air Changes Per Hour............................................. 16

Table 7: Minimum Attic Net free Ventilation Area Based on Fan Capacity....................................... 21

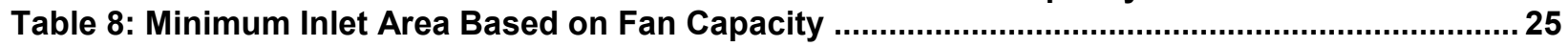

Table 9: Outdoor Air and Return Duct Sizing Recommendations .................................................. 26

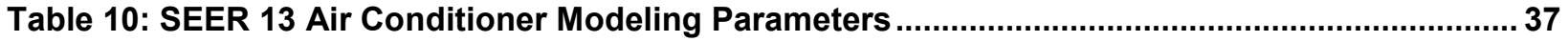

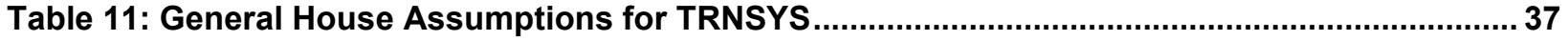

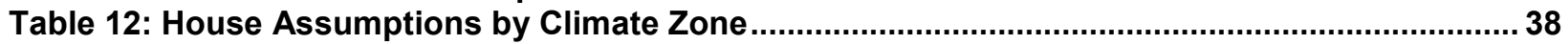

Table 13: Base Case Cooling Energy Use by Climate Region. .................................................... 38

Table 14: Sacramento Energy Savings and Utility Savings Based on Standard and TOU Rates .... 39

Unless otherwise noted, all tables were created by the ARBI team. 


\section{Definitions}

$\mathrm{AC}$

ACCA

$\mathrm{ACH}$

AMCA

ANSI

ARBI

ASHRAE

Btu

CARB

CFA

cfm

DEG

ECM

${ }^{\circ} \mathrm{F}$

HVAC

HVI

IECC

$\mathrm{kW}$

kWh

LBNL

NFVA

NOAA

oc

PG\&E

PSC

RH

RPM

SHGC

sq $\mathrm{ft}$

TOU
Air conditioner

Air Conditioning Contractors of America

Air changes per hour

Air Movement \& Control Association

American National Standards Institute

Alliance for Residential Building Innovation

American Society of Heating, Refrigerating, and Air

Conditioning Engineers

British thermal unit

Consortium for Advanced Residential Buildings

Conditioned floor area

Cubic feet per minute

Davis Energy Group

Electronically commutated motor

Degrees Fahrenheit

Heating, ventilation, and air conditioning

Home Ventilation Institute

International Energy Conservation Code

Kilowatt

Kilowatt-hour

Lawrence Berkeley National Laboratory

Net free vent area

National Oceanic and Atmospheric Administration

On center

Pacific Gas and Electric Company

Permanent-split capacitor (motor)

Relative humidity

Revolutions per minute

Solar heat gain coefficient

Square feet

Time-of-use (utility rate) 
\begin{tabular}{l|l} 
U.S. DEPARTMENT OF & Energy Efficiency \& \\
Renewable Energy
\end{tabular}

VOC

W
Volatile organic compound

Watt 


\section{Executive Summary}

The purpose of this measure guideline on ventilation cooling is to provide information on a cost effective solution for reducing cooling system energy and demand in homes located in hot-dry and cold-dry climates. This guideline provides a prescriptive approach that outlines qualification criteria, selection considerations, and design and installation procedures. This document has been prepared to provide the following audiences with a process for properly applying, designing and installing mechanical ventilation cooling systems and a means of understanding the benefits, costs, and tradeoffs:

- Builders

- HVAC contractors

- General contractors

- Homeowners.

Mechanical ventilation cooling is a simple cooling strategy that can be effective in a variety of climates that experience significant outdoor diurnal temperature variations. The technology is not appropriate for all climates, and the guidelines set forth in this document identify climates where ventilation cooling can reduce energy use and in some cases replace air conditioning, while maintaining comfort. Savings can be enhanced by employing "passive" principals that include solar orientation, high performance windows and reducing glazing area, high insulation levels, and exposed distributed thermal mass in the home. Best practices for moisture management and controlling air movement should always be followed.

\section{Acknowledgements}

Davis Energy Group would like to acknowledge the United States Department of Energy Building America (BA) program and their funding and support of development of this guideline as well as research that informed it. In addition, we would like to acknowledge the California Energy Commission Public Interest Energy Research (PIER) Program and the California Institute for Energy and Environment (CIEE) for supporting the Alternatives to Compressor Cooling project which supplied a large body of research on residential ventilation cooling. 


\section{Section 1:Introduction}

Residential air conditioning has become increasingly common throughout the United States over the past 30 years as comfort demands have increased and market demands have pushed compressor-based cooling into climates not previously seen. Increasingly, air conditioners are being installed in milder, transitional climates to compensate for these increased comfort demands, as well as increased building loads seen from the trend towards larger homes and greater window areas. The 2009 Residential Energy Consumption Survey (RECS) shows that $61 \%$ of residential homes have central air conditioning. This is up significantly from $47 \%$ in 1997 and only $23 \%$ in $1978 .{ }^{1}$

Mechanical ventilation cooling is a simple cooling strategy that can be effective in a variety of climates that experience significant outdoor diurnal temperature variations. This strategy can eliminate the need for air conditioning in mild climates and reduce air conditioner energy use and installed air conditioner capacity in hotter climates.

\section{Passive Ventilation Cooling}

The effectiveness of passively cooling a home through opening of windows is based upon:

- Effective open area of windows for incoming air and area of exhaust ports for exhaust air;

- $\quad$ Stack effect ventilation potential based on height differences between open ventilation paths;

- Effectiveness of wind-induced ventilation based on wind speed, prevailing wind direction, and placement of windows; and

- Temperature difference between indoors and outdoors.
"Passive" ventilation cooling, obtained by opening windows at night and closing them during the day, has long been employed as a means of keeping homes cool, and prior to the 1950s was the primary resource most people had for maintaining indoor comfort in summer. However, the effectiveness of passively cooling a home is limited by climatic conditions and geometry and orientation of the home, which are for the most part out of the control of occupants. In addition, fewer people open windows nowadays due to concerns of safety, the introduction of unwanted dust and noise into the home, and the prevalence of central heating and cooling systems that require closed homes to operate effectively. A 2006 Lawrence Berkeley National Laboratory (LBNL) study found that $20 \%$ of California households never open windows and 50\% rarely open windows (Price, et al 2006).

The principles of ventilation cooling, whether passive or mechanical, are that cool nighttime air is introduced into the house, replacing warmer indoor air. Heat from building mass elements, such as interior surfaces and furnishings, is

transferred to the ventilation air, which is then discharged from the house. During the daytime, the cool building mass absorbs heat from the air and warm outdoor environment, moderating the rise in indoor temperature. Effective ventilation cooling can only occur while nighttime outside air temperatures are cooler than indoor air. The rate of cooling is somewhat proportional to the volume of air moved and its contact with mass surfaces, so fans can significantly improve cooling performance, particularly on still nights and with larger homes without good cross

\footnotetext{
${ }^{1}$ http://www.eia.gov/emeu/consumptionbriefs/recs/actrends/recs_ac_trends.html
} 
ventilation. Cooling performance is also improved by the use of building materials with high levels of thermal mass distributed throughout the home, such as concrete and masonry, which have the ability to store larger amounts of heat, and by ensuring a tight, insulated building construction that reduces undesirable air movement and heat transfer.

While passive systems are desirable from a simplicity standpoint, active mechanical systems are more appropriate for the majority of housing stock due to the limitations described above. Primary advantages associated with mechanical ventilation cooling include:

- Energy and cost savings from the reduction or elimination of air conditioner use

- Peak demand savings - potential to shift cooling from on- to off-peak periods

- Improved occupant comfort due to lower daily average indoor temperatures during the summer

- Improved indoor air quality.

The larger interior temperature range that the occupant is willing to endure, the greater the energy and peak demand savings potential. On a hot summer day, the lower the temperature the house reaches the previous night, the more comfortable the house will stay during the day and the greater the possibility that the house will be able to ride out the peak afternoon event without air conditioning operation. The benefits of ventilation cooling will be diminished for occupants with narrow comfort and temperature requirements.

\subsection{Types of Systems}

There are two primary types of mechanical ventilation cooling systems: whole house fans and central fan systems. Whole house fans are an occupant-controlled low cost solution. They are typically installed in the ceiling and exhaust air into the attic through a louver mounted in the ceiling, as shown in Figure 1. Most are designed to fit between 24" on-center joists. Other installation configurations may be possible but will not be discussed in this document.

Traditional whole house fans, "propeller style", have an uninsulated damper that is operated by air pressure, and a belt or direct drive motor driving a propeller. Some newer models incorporate an insulated motorized damper. These fans, which will be referred to as "insulated damper style", commonly have lower airflow rates and some have variable speed capabilities.

As a manually operated system, whole house fans require the occupant to remain cognizant of indoor and outdoor conditions and to open windows and switch on the fan as soon as the outdoor air temperature falls below the indoor temperature. As the outdoor temperature warms relative to the indoor temperature, the fan must be turned off and windows closed. It is possible to provide controls to automatically operate a whole house fan, but there are no such products currently available. The system would require motorized outdoor air dampers that would be remotely controlled to bring in cooler outdoor air during operation.

Manufacturers typically provide guidance on the amount of vent area required for their products. Otherwise, general guidelines are provided in this document and should be followed. If the area of attic vents is less than required, it may be necessary to increase the size of the vent openings in order to provide adequate air relief. Some whole house fans can be ducted directly to the exterior and can therefore be used in houses with non-vented attics. 


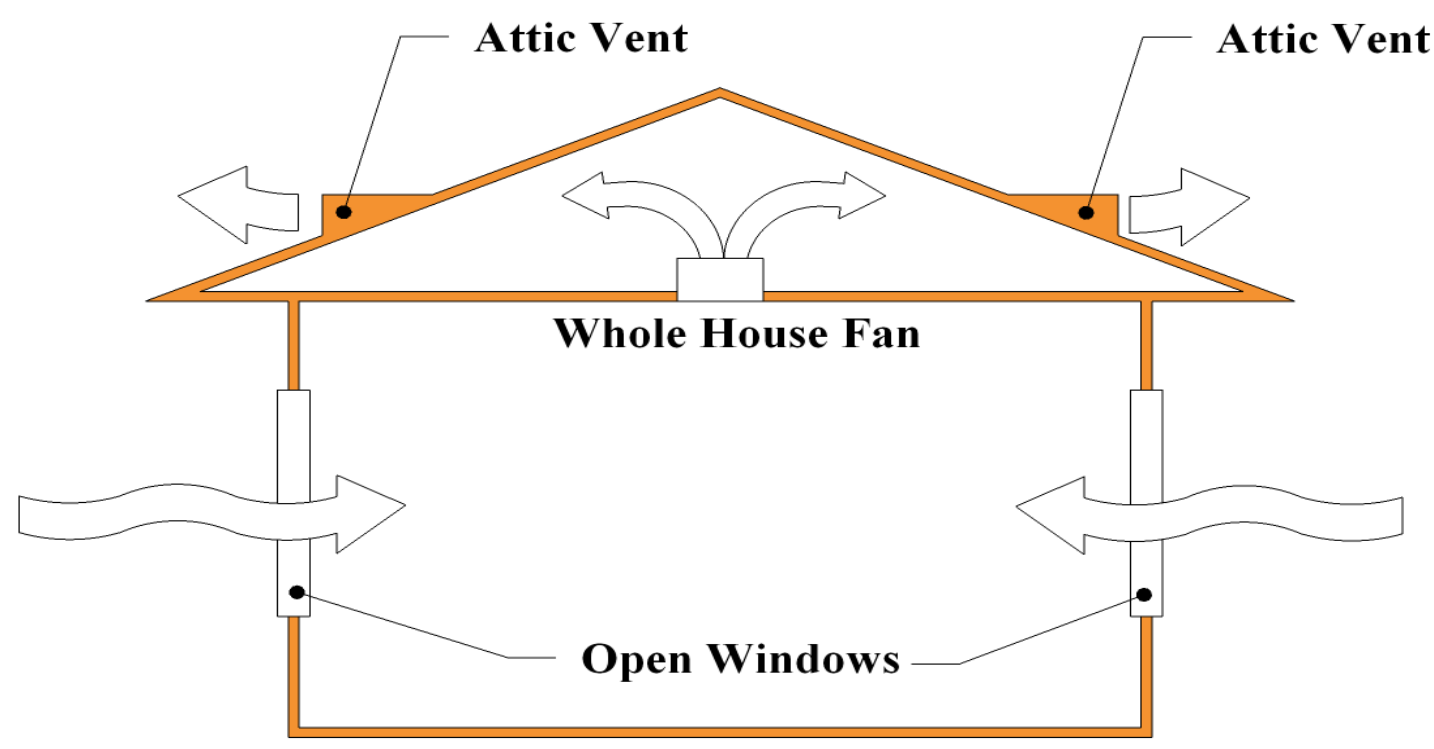

Figure 1: Whole house fan operation

Central fan systems use the house's heating and cooling furnace or air handler fan to deliver outdoor air, which is distributed through the duct system. A motorized damper switches between return air from the house and outside air, and allows warmer indoor air to be relieved into the return duct zone, typically the attic, or ducted directly to outdoors when the system is ventilating. With systems located in spaces other than the attic (basement or crawlspace) or when space availability is a concern, exhaust relief air can be ducted directly to outside. A control system that is integrated with the heating-cooling thermostat automatically operates the system when the indoor-outdoor temperature difference is in the correct range. Figure 2 and Figure 3 depict functionality in both modes for a system with the air handler and ductwork located in the attic. In Figure 2, the system is in normal cooling mode, with air being drawn from and returned to the house. Figure 3 shows the damper in the "vent" position, which allows the fan to draw air from outdoors, supply it to the house, and discharge it into the attic. As with whole house fans, flushing the attic with cool air allows the house to cool down more quickly. With systems located in a basement or crawlspace or where there is a ducted relief this will not be an advantage.

Advantages of central fan systems relative to whole house fans include:

- Automatic control of the system ensures more optimal operation and allows the system to initiate ventilation when the occupants are away from home or asleep

- Windows do not need to be opened, improving security and reducing indoor noise pollution

- Ventilation air is filtered to remove dust and pollens

- System controls can prevent over-cooling

- Availability of an "economizer" mode: If the air conditioner operates while the outdoor temperature is lower than the indoor temperature, outdoor air will be delivered to the 
cooling coil instead of indoor air, resulting in higher system capacity, higher operating efficiencies, and less energy use.

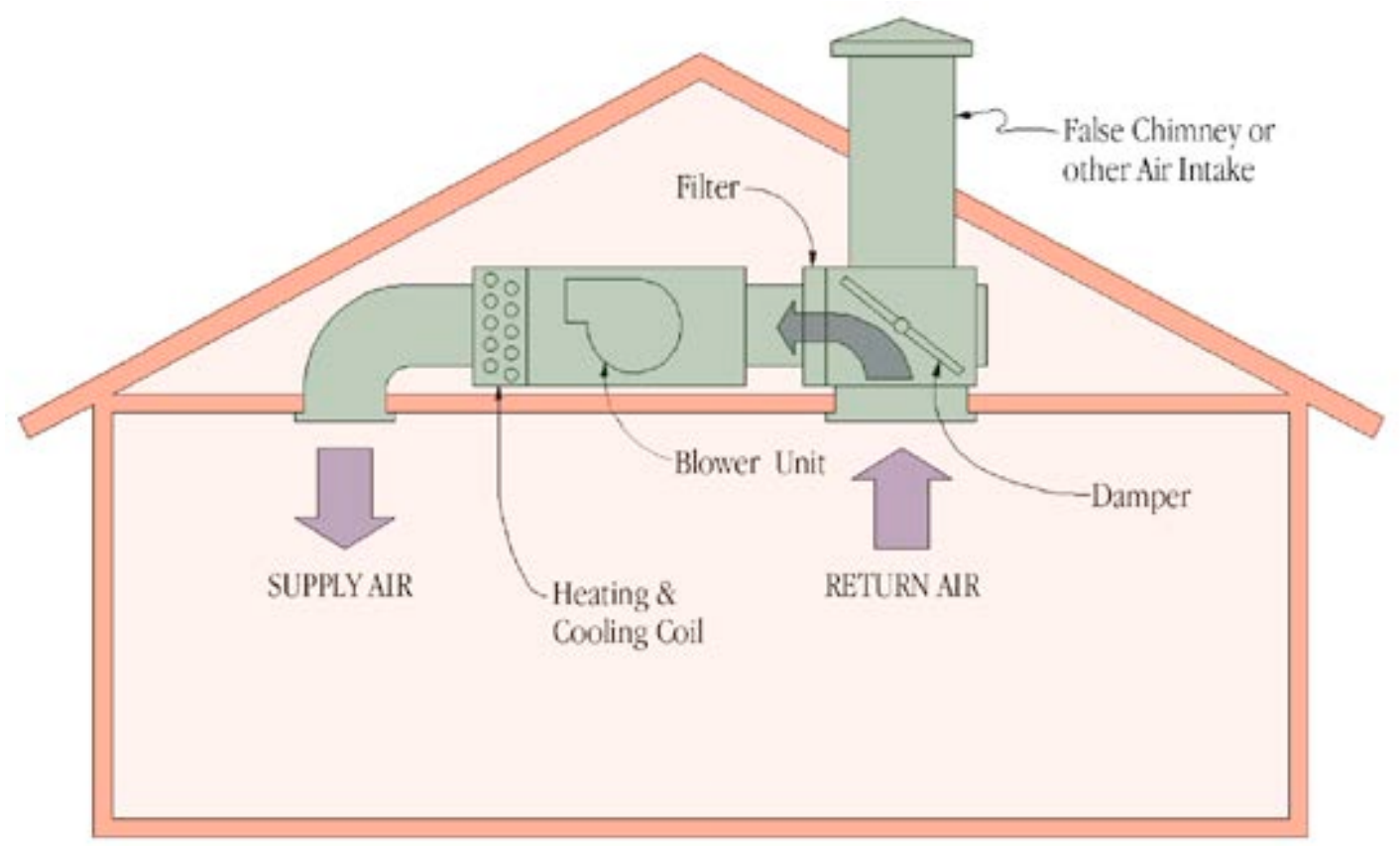

Heating \& Air Conditioning

Figure 2: Central fan system operation in standard air conditioning mode

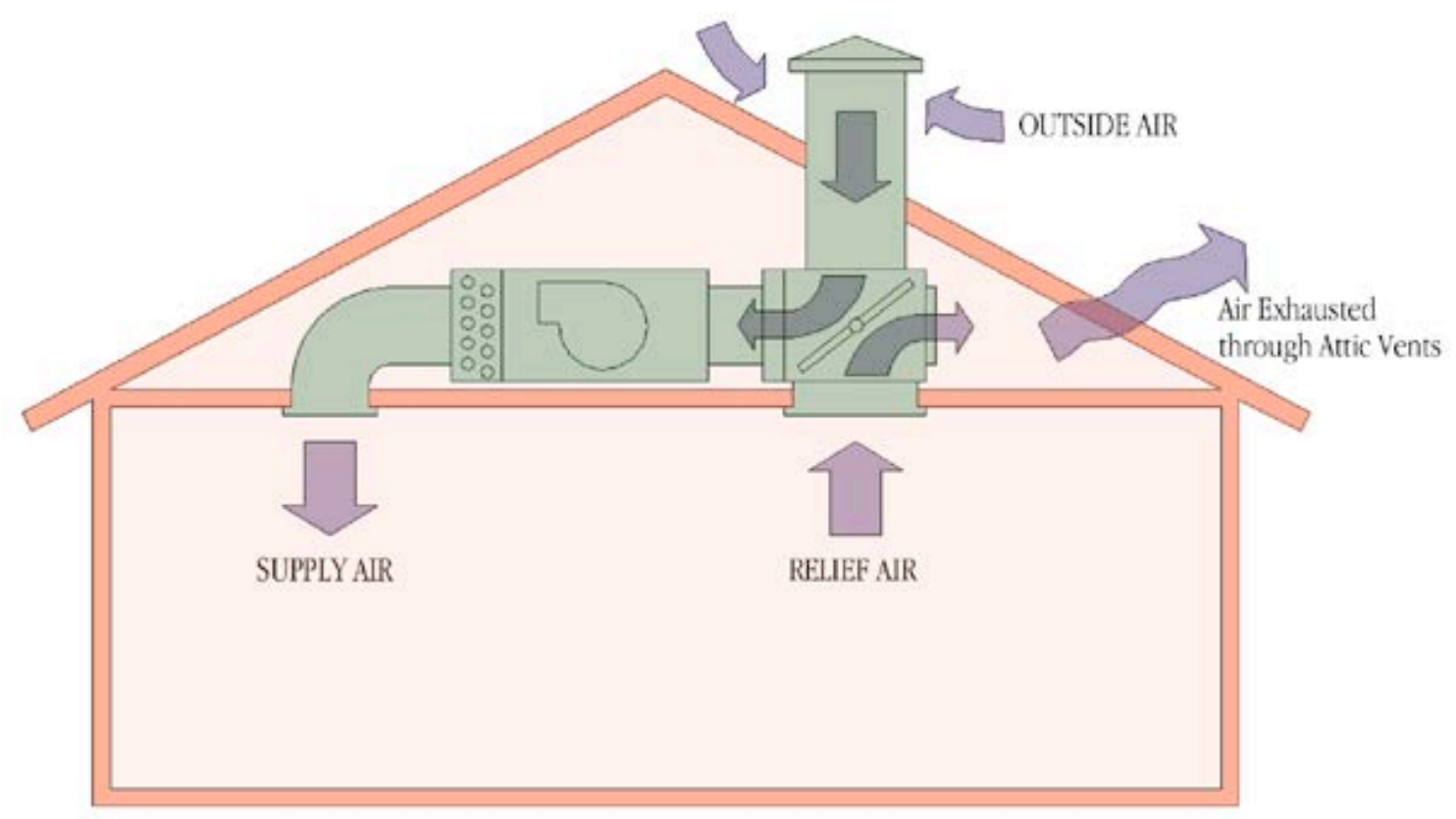

Ventilating

Figure 3: Central fan system operation in ventilation cooling mode 


\section{Section 2: Tradeoffs}

\subsection{System Tradeoffs}

There exist unique advantages and disadvantages associated with the two primary types of ventilation cooling systems. Table 1 outlines the tradeoffs between whole house fans and central fan systems. These tradeoffs are discussed further below and additional details on design considerations can be found in Section 3.

\section{Definition}

Fan Efficacy: The efficiency with which a fan is able to move air, measured in Watts / cfm. This is calculated as the power (Watts) required to operate the fan at a specific airflow divided by the airflow rate $(\mathrm{cfm})$.

Table 1: Tradeoffs Between Ventilation Cooling System Types

\begin{tabular}{|c|c|c|}
\hline & Whole House Fans & Central Fan Systems \\
\hline Cost & Lower cost & More expensive \\
\hline $\begin{array}{l}\text { Airflow \& Fan } \\
\text { Efficacy (cfm } \\
\text { per Watt) }\end{array}$ & $\begin{array}{l}\text { Potential for high airflow, } \\
\text { relatively high fan efficacy }\end{array}$ & $\begin{array}{l}\text { Lower airflow rate and } \\
\text { higher fan efficacy due to } \\
\text { fan type and restrictions }\end{array}$ \\
\hline $\begin{array}{l}\text { Indoor Air } \\
\text { Quality }\end{array}$ & No outdoor air filtration & Filters outside air \\
\hline Noise & Noisy (most models) & Quiet \\
\hline Health \& Safety & Potential back draft concerns & No back draft concerns \\
\hline Comfort & $\begin{array}{l}\text { Non-insulated dampers } \\
\text { result in heat gains/losses }\end{array}$ & No comfort concerns \\
\hline Installation & Easy installation & $\begin{array}{l}\text { Easy integration w/ ducted } \\
\text { HVAC; may be space } \\
\text { limitations and additional } \\
\text { controls are necessary }\end{array}$ \\
\hline Operation & $\begin{array}{l}\text { Requires manual opening } \\
\text { and closing of windows }\end{array}$ & $\begin{array}{l}\text { Automated operation w/ } \\
\text { ability to control setpoint }\end{array}$ \\
\hline Maintenance & Minimal & $\begin{array}{l}\text { Potential damper leakage, } \\
\text { frequent filter replacement }\end{array}$ \\
\hline $\begin{array}{l}\text { Cooling } \\
\text { Performance }\end{array}$ & $\begin{array}{l}\text { Dependent on occupant } \\
\text { behavior and weather }\end{array}$ & $\begin{array}{l}\text { Primarily dependent on } \\
\text { weather }\end{array}$ \\
\hline
\end{tabular}

\section{Cost}

Whole house fans are typically less expensive than central fan systems and are widely represented in the market; costs depend on the type. Belt driven fans range in price from $\$ 150$ to $\$ 300$ while those with insulated dampers may cost up to $\$ 1,500$. There are currently a limited number of central fan systems on the market. Because of additional system components such as controls and dampers, central fan systems add around $\$ 900-\$ 2,400$ to the cost of a standard central HVAC system. If manufactured in volume there is a strong possibility that this cost would be reduced. 
In mild climates, ventilation cooling can eliminate the need for compressor-based cooling, thereby resulting in a negative incremental capital cost. Two of the central fan systems manufactured incorporate zone controls and one also includes a winter fresh air ventilation function, which can result in cost tradeoffs where zoning and fresh air ventilation (compliant with ASHRAE Standard 62.2) must be provided.

Incentives for installation of ventilation cooling systems may be available for either new construction or retrofit installations. Check with the local utility to determine if rebates or other energy credits are available.

\section{Airflow and Fan Efficacy}

Whole house fans have the potential to move large volumes of air and typically have fan motors that operate more efficiently than central ducted systems, which have to deal with larger pressure drops and system friction. Whole house fans are available that have maximum rated airflows between $750 \mathrm{cfm}$ and 10,000 $\mathrm{cfm}$. Central fan system airflows are usually similar to cooling system design airflow for dry climates (400 cfm per ton) and range from 600 to 2,000 cfm for typical house sizes. The lower airflow requires longer fan run times to achieve equivalent cooling effect.

\section{HVI Publication 916:} Airflow Test Procedure.

The Home Ventilation Institute's (HVI) Airflow Test Procedure (HVI-916) certifies fan airflow in cubic feet per minute (cfm) and fan power in Watts at specified pressure conditions. This is the same test procedure that is used to certify residential exhaust fans.
The energy performance of fans is often characterized using a metric called fan efficacy which is defined as the power required to move a certain volume of air $(\mathrm{W} / \mathrm{cfm})$. Large, propeller style whole house fans generally have better efficacies (lower W/cfm) than other types of whole house fans. However, many smaller fans have variable speed capabilities which allow for better efficacy operation at lower airflows. Fan performance data for whole house fans can be found from testing performed by the Home Ventilation Institutes (HVI), which certifies fans according to their Airflow Test Procedure (HVI-916).

Central fan systems can be driven by either a variable speed electronically commutated motor (ECM) or a permanent split capacitor (PSC) motor. ECMs have two characteristics that distinguish them from PSCs: they have better efficacy and most types can deliver a relatively constant airflow over a wide range of external static pressures. These "regulated cfm" motors respond to increasing static pressure by ramping up torque and RPM, which results in their drawing more power. Therefore, proper distribution system design is needed to insure that their improved efficacy is realized. For more information on fan airflow and efficacy see Attachment B.

\section{Non-Energy Benefits}

Ventilation cooling improves indoor air quality by replacing stale indoor air with fresh outdoor air. Managing indoor air quality has become increasingly important as new homes become tighter and concerns grow about buildup of chemicals such as formaldehyde and volatile organic compounds (VOCs) from furniture, building materials, carpeting, and other items that we bring into our homes. Variable speed central fan

\section{Reference}

ASHRAE Standard 62.2 - 2010: Ventilation and Acceptable Indoor Air Quality in Low-Rise Residential Buildings. 
ventilation cooling systems have the potential to be programmed to comply with ASHRAE 62.2 and to take advantage of intermittent ventilation provisions in the standard to avoid delivering air to houses during the hottest or coldest periods of the day.

Ventilation cooling systems can also provide improved comfort with minimal impact on energy use. At a $15^{\circ} \mathrm{F}$ difference between indoor and outdoor temperature, a fan moving $1200 \mathrm{cfm}$ will deliver approximately $18,000 \mathrm{Btu} / \mathrm{h}$ of cooling, after taking into account fan heat added to the airstream. Assuming a conservative storage efficiency of the building thermal mass within the home of $50 \%$ and that the fan motor draws 360 Watts, the equivalent energy efficiency ratio of the ventilation cooling system would be 25 Btu per Watt-hour. A high efficiency air conditioner running during the daytime may operate at efficiencies around 14 Btu per Watt-hour or even much lower when outdoor temperatures are high.

\section{Installation, Operation and Maintenance}

Whole house fans are appropriate for existing as well as new homes. Central fan systems are generally limited to new homes where space for dampers and provisions for outside air intakes have been allowed for in the design. Variable speed central fan systems require the use of compatible furnace, heat pump, or air handler products, and are therefore limited to new home applications or retrofits where the HVAC system is being replaced.

Installation procedures are generally not complicated for either whole house fans or central fan systems. In both cases space limitations must be considered and the most appropriate location for installation identified. Central fan systems require adequate space at the return plenum for installation of the damper box. This may cause complications when the furnace or air handler is installed in a closet or other location where space is limited.

The amount of non-compressor cooling that can be obtained depends on how low below the air conditioner setpoint the house can be cooled. If the house is only allowed to be cooled by a degree or two below the set point, little cooling will be stored in the building mass, and only a small amount of air conditioner operation will be offset.

Whole house fans require very minimal maintenance. Most importantly, fans using non-insulated dampers should be covered during the winter to minimize heat losses to the attic space. Central fan systems require more frequent air filter replacement than standard ducted HVAC systems because they have more hours of operation and filter outside air as well as return air. Dampers should be tested for air tightness after installation and periodically inspected to verify that damper motors and linkages are operating correctly.

\subsection{System Interactions}

Ventilation cooling can be effective in a variety of home types located in appropriate climates, but greater benefit will be obtained in well-insulated, tight homes with passive design features, including proper orientation, building shading and higher levels of thermal mass. Thermal mass (or the capacity of a material to store heat) acts to temper increases in interior space temperatures as outdoor temperatures rise. Inexpensive strategies for increasing a home's thermal mass include the following:

- Exposed slab floors or the use of hard surface floor coverings over slab floors (tile, wood, or vinyl) instead of carpet 
- Use of masonry or other high mass wall construction materials

- Use of $5 / 8$ " instead of $1 / 2$ " drywall, or double drywall layers

- Apply gypsum concrete topping over upper level sub-floors (which also reduces noise and improves fire safety)

Attention to other measures that increase the performance of the building "envelope", or shellincluding exterior walls, ceiling, floors, windows, and doors - will reduce the cooling load and increase both the performance and efficiency of the heating, cooling, and ventilation systems.

- Insulation keeps homes warm in the winter and cool in the summer by reducing heat transfer. Insulate exterior surfaces to levels recommended by best practices for the climate region and required by local building codes. Insulation performance is measured by R-value; higher R-values are more insulative.

- High performance glass with a low U-value (high R-value) will reduce heat transfer. In hot climate regions, windows should also have a low solar heat gain coefficient (SHGC) which reduces gains from incoming solar radiation. In cold climates, the tradeoff between cooling and heating savings should be evaluated.

- Minimize unintentional infiltration and exfiltration by caulking or otherwise sealing all penetrations and gaps to prevent air movement between conditioned and unconditioned space. Areas of focus include attics, basements, wire and plumbing penetrations, windows, and doors.

- When possible, proper building orientation and window placement can take advantage of the benefits of prevailing winds, onsite shading, passive solar and daylighting. Shading of west and east facing walls and, particularly, windows during the summer will reduce the cooling load.

\subsection{Climate Considerations}

Night ventilation cooling systems are most effective in dry climates which have both significant cooling loads and outdoor diurnal temperature swings. The map in Figure 4 illustrates generally where the installation of ventilation cooling systems in the United States will be most effective. Note that this map is to be used as a general reference only and local weather climatic normal data should be reviewed to determine if ventilation cooling is appropriate for any specific location. A more detailed description of how this map was developed can be found in Attachment C.

\section{Definition}

Diurnal Temperature Swing: The difference between the daily outdoor high and low temperatures. 


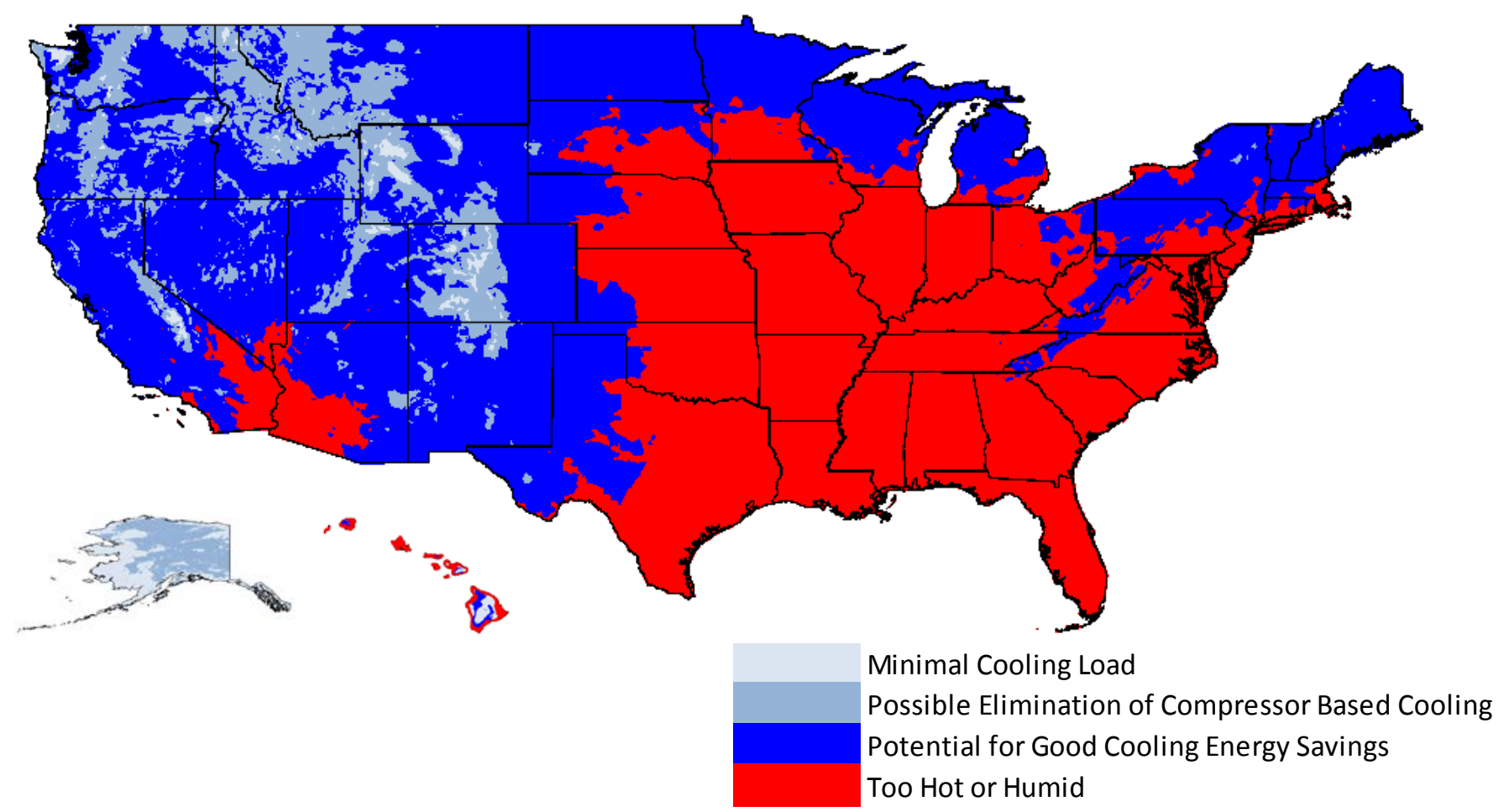

Figure 4: Favorable climates for ventilation cooling

Note

Check with the National Climatic Data Center for archived local weather data. http://www.ncdc.noaa.gov. Other sources of data include typical meteorological year (TMY) data sets from NREL

http://rredc.nrel.gov/solar/old_data/ nsrdb/1991-2005/tmy3/.

marine climates, such as the Pacific Northwest, cooler temperatures may warrant elimination of traditional air conditioning systems through the use of ventilation cooling. Ventilation cooling is not recommended in regions where the enthalpy of outdoor air (during summer nights) is commonly higher than that of desired indoor air conditions. Central fan systems can be designed to control ventilation cooling based not only on the sensible temperature (dry-bulb) but enthalpy as well, but no such systems currently exist. While there may be days in hot-humid climates, during the swing seasons, when ventilation cooling is very useful, it is more difficult to justify cost effectiveness because of increased air conditioner use for dehumidification purposes.

\section{Definition}

Enthalpy: The enthalpy of the air describes its total energy content including that due to sensible heat and latent heat. Sensible heat is that which we can sense and is associated with the dry-bulb temperature. Latent heat is related to the amount of moisture contained in the air. 


\subsection{Energy Savings}

In hot-dry and cold-dry climates, the use of ventilation cooling can significantly reduce, delay, or completely eliminate air conditioner operation resulting in both energy savings and reduction of

peak demand. These savings stem from the use of the fan

\section{Definition}

Peak Demand: The period during the day in which utilities expect to supply higher than average levels of electricity for a sustained period of time. Many utilities define the peak period as between 1:00 pm and 7:00 pm. only, instead of the compressor plus fan, to maintain indoor comfort. The amount of energy saved is a function of nighttime temperatures, airflow rate, and effectiveness of thermal mass, as well as the amount of pre-cooling, or cooling below the thermostat setpoint, the homeowner is willing to tolerate. Peak demand savings are achieved by shifting daytime air conditioner use to nighttime fan operation. Some utilities offer time-of-use (TOU) rate schedules which apply higher rates during on-peak periods than during off-peak periods, resulting in additional cost savings.

Prior field studies and simulations completed under the Alternatives to Compressor Cooling program (Springer 2004) and through Building America (BA) research (CARB 2009) identified energy savings for central fan type systems and verified their ability to eliminate air conditioning in specific mild climates. In order to estimate energy savings for both whole house fan and central fan systems in a variety of climates, a typical house was modeled using TRNSYS 17. Three night ventilation scenarios were modeled using TRNSYS: whole house fan, variable speed central fan, and fixed speed central fan. Modeling applied air conditioning to supplement ventilation cooling in all climates. Marine climate simulations were also completed with no supplemental air conditioning to determine whether comfort could be maintained with ventilation cooling alone.

The house used in the models was a typical 2,400 $\mathrm{ft}^{2}$ single story home, and applied design assumptions were based on the Building America Benchmark House Simulation Protocols that correspond to the climate zones in which the house was modeled (DOE, 2010). A complete list of house design parameters by climate zone are provided in Attachment D. Fan efficacy was determined from manufacturers' data for whole house fans, and from laboratory tests of PSC and ECM motors for the central fan system types. Variable speed fan airflow and energy use was calculated as a function of the previous day's maximum temperature, which is a simplification of the control algorithm used in manufactured systems. The cooling setpoint for the house was $76^{\circ} \mathrm{F}$ and the nighttime ventilation setpoint for central fan systems was $65^{\circ} \mathrm{F}$.

Specific climates were selected for evaluation based on their average high temperatures and diurnal temperature swings. Hot-humid and mixed-humid climates were not evaluated because of their low diurnal swings and high humidity. Cooler marine climates (Pacific Northwest) were not evaluated because air conditioning is not typically installed. Figure 5 shows nationally where both the Building America and IECC climate zones are located. 

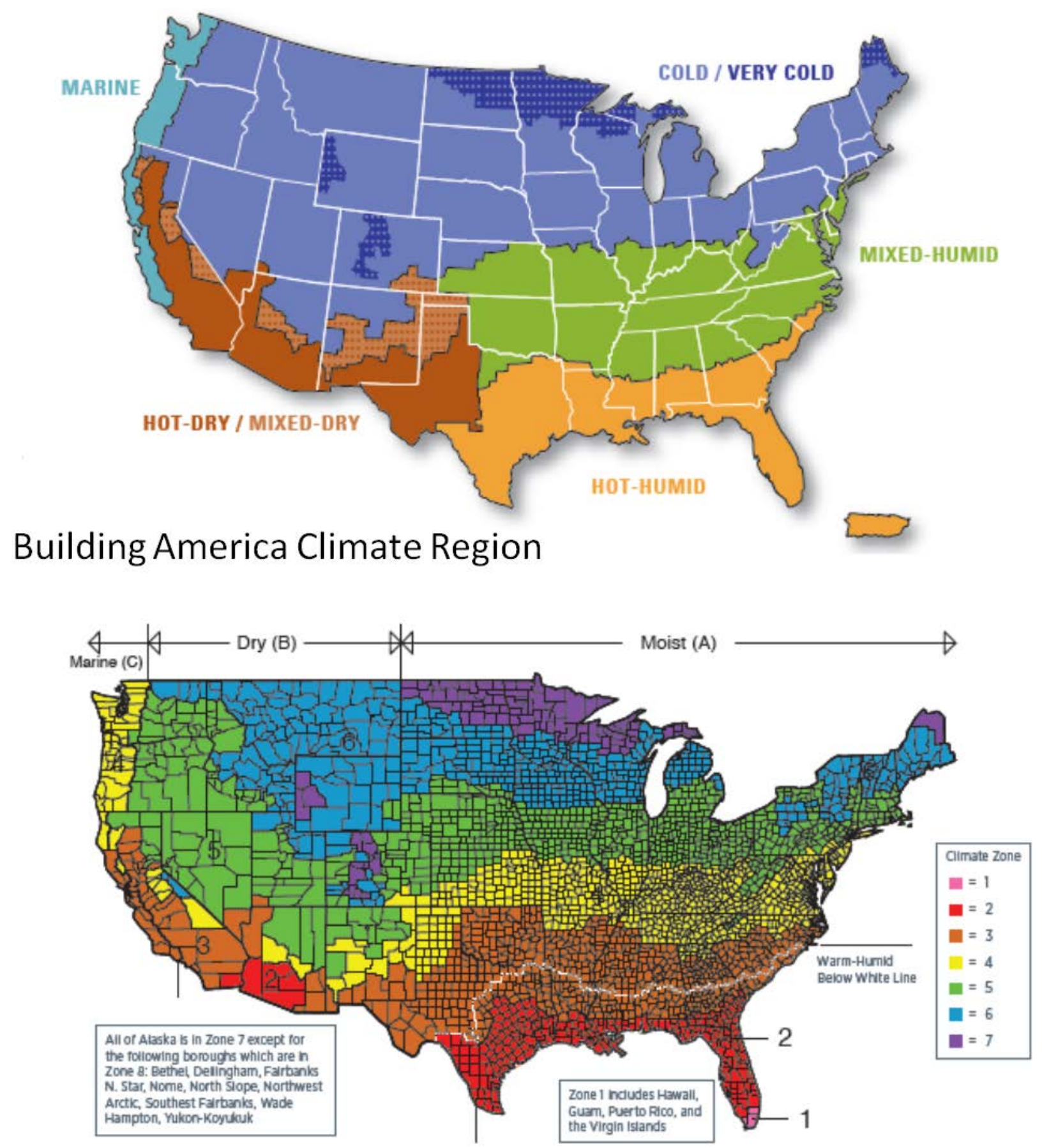

IECC Climate Zone

Figure 5: Building America and IECC climate zone reference map 


\section{Whole House Fans}

Whole house fan savings predicted by the simulations, shown in Table 2, assume ideal operation and occupant control, and are therefore optimistic since this type of operation requires a very high level of diligence on the part of the homeowner and willingness to be present to operate the system at all times. Fan performance was based on an insulated damper style fan with a fan efficacy of $0.15 \mathrm{~W} / \mathrm{cfm}$.

Table 2: Estimated Energy Savings for Whole House Fans

\begin{tabular}{l|c|l|c|c}
\hline $\begin{array}{c}\text { Building } \\
\text { America } \\
\text { Climate Region }\end{array}$ & $\begin{array}{c}\text { IECC } \\
\text { Climate } \\
\text { Zone }\end{array}$ & Location & $\begin{array}{c}\text { Annual Energy } \\
\text { Savings } \\
\text { (kWh) }\end{array}$ & $\begin{array}{c}\text { \% Cooling } \\
\text { Energy } \\
\text { Savings }\end{array}$ \\
\hline \hline Hot-Dry & 3B & Sacramento, CA & 212 & $20 \%$ \\
\hline Marine & 3C & Santa Rosa, CA ${ }^{2}$ & 58 & $48 \%$ \\
\hline Mixed-Dry & 4B & Albuquerque, NM & 173 & $14 \%$ \\
\hline Cold & 5B & Denver, CO & 308 & $33 \%$ \\
\hline Cold & 6A & Burlington, VT & 124 & $34 \%$ \\
\hline
\end{tabular}

Table 2 shows that savings are greatest for ventilation cooling in hot-dry and cold-dry climates with large diurnal swings. Mild climates like Santa Rosa exhibit high percent cooling savings but since cooling loads are small, the absolute savings potential in $\mathrm{kWh}$ is minimal. However, in these climates it is assumed that ventilation cooling would replace the installation of compressor based air conditioning resulting in the potential for up-front cost savings.

\section{Central Fan Systems}

The cooling setpoint for the house was assumed to be $76^{\circ} \mathrm{F}$ and the ventilation setpoint was $65^{\circ} \mathrm{F}$. As illustrated by Table 3 and Table 4, variable speed fan operation is critical to obtaining any real energy savings from central fan systems. Modeling of fixed speed fans shows an increase in total cooling energy use in all climate zones. In marine climates, the increase in fan energy use is greater than the total base case cooling energy use. Prior studies have shown comparable peak load reductions for the two system types (PG\&E, 2008). Fixed speed fans may show better performance with a higher nighttime ventilation cooling setpoint, but this will diminish the cooling load reduction on

California Title-24 Energy Code

California is evaluating the potential for including credit for ventilation cooling systems in the upcoming version of the Title-24 energy code. Preliminary modeling projects over $32 \%$ cooling electricity savings for central fan systems and $15 \%$ cooling savings for whole house fans in hot-dry climates. The proposed standard reduces modeled whole house fans savings, by $75 \%$ to account for nonideal operation. the AC compressor on peak summer days. Key to the success of the variable speed systems is the variation of airflow with cooling demand, and the substantial decrease in fan efficacy and reduction of fan power at lower airflow rates.

\footnotetext{
${ }^{2}$ The Marine climate region results assume no AC compressor cooling.
} 
Table 3: Estimated Energy Savings for Variable Speed Central Fan Ventilation Cooling Systems

\begin{tabular}{l|c|l|c|c}
\hline $\begin{array}{c}\text { Building } \\
\text { America } \\
\text { Climate Region }\end{array}$ & $\begin{array}{c}\text { IECC } \\
\text { Climate } \\
\text { Zone }\end{array}$ & Location & $\begin{array}{c}\text { Annual Energy } \\
\text { Savings } \\
\text { (kWh) }\end{array}$ & $\begin{array}{c}\% \text { Cooling } \\
\text { Energy } \\
\text { Savings }\end{array}$ \\
\hline \hline Hot-Dry & 3B & Sacramento, CA & 135 & $13 \%$ \\
\hline Marine & 3C & Santa Rosa, CA & 58 & $11 \%$ \\
\hline Mixed-Dry & 4B & Albuquerque, NM & 150 & $12 \%$ \\
\hline Cold & 5B & Denver, CO & 203 & $22 \%$ \\
\hline Cold & 6A & Burlington, VT & 116 & $32 \%$ \\
\hline
\end{tabular}

Table 4: Estimated Energy Savings for Fixed Speed Central Fan Ventilation Cooling Systems

\begin{tabular}{l|c|l|c|c}
\hline $\begin{array}{c}\text { Building } \\
\text { America } \\
\text { Climate Region }\end{array}$ & $\begin{array}{c}\text { IECC } \\
\text { Climate } \\
\text { Zone }\end{array}$ & Location & $\begin{array}{c}\text { Annual Energy } \\
\text { Savings } \\
\text { (kWh) }\end{array}$ & $\begin{array}{c}\text { \% Cooling } \\
\text { Energy } \\
\text { Savings }\end{array}$ \\
\hline \hline Hot-Dry & 3B & Sacramento, CA & -2 & $0 \%$ \\
\hline Marine & 3C & Santa Rosa, CA & -125 & $-104 \%$ \\
\hline Mixed-Dry & 4B & Albuquerque, NM & -77 & $-6 \%$ \\
\hline Cold & 5B & Denver, CO & -43 & $-5 \%$ \\
\hline Cold & 6A & Burlington, VT & -195 & $-53 \%$ \\
\hline
\end{tabular}

\section{Cooling Energy Tradeoffs}

Figure 6 compares TRNSYS predictions of cooling energy use for each of the system types to the base case for the hot-dry climate of Sacramento. Because of its high air ventilation rate and fan efficacy, the ideally operated whole house fan shows the greatest reduction of air conditioner energy use and the least amount of ventilation fan energy. The fixed speed central fan system completely trades off fan energy use for air conditioner savings.

Potential savings with whole house fans are higher than savings calculated for central fan systems, but as stated above, assume ideal operation and control, which might not be possible in many situations where occupants do not leave windows open for extended periods of time and don't always initiate ventilation cooling when temperature conditions are met (i.e. in the middle of the night). Additionally, the modeling algorithm used for estimating ventilation cooling operation assumes a fixed ventilation setpoint of $65^{\circ} \mathrm{F}$. Controls are available in variable speed central fan systems that adjust the daily ventilation setpoint based on the previous day's weather to avoid overcooling under mild conditions. While this strategy could not be modeled, it would result in lower fan use and additional savings for the variable speed central fan ventilation systems.

Central fan ventilation systems have the ability to run in economizer mode in conditions where the AC is operating and outdoor temperatures are cooler than indoor. This mode of operation was not included in the analysis above.

\footnotetext{
${ }^{3}$ The Marine climate region results assume no AC compressor cooling.

${ }^{4}$ The Marine climate region results assume no AC compressor cooling.
} 


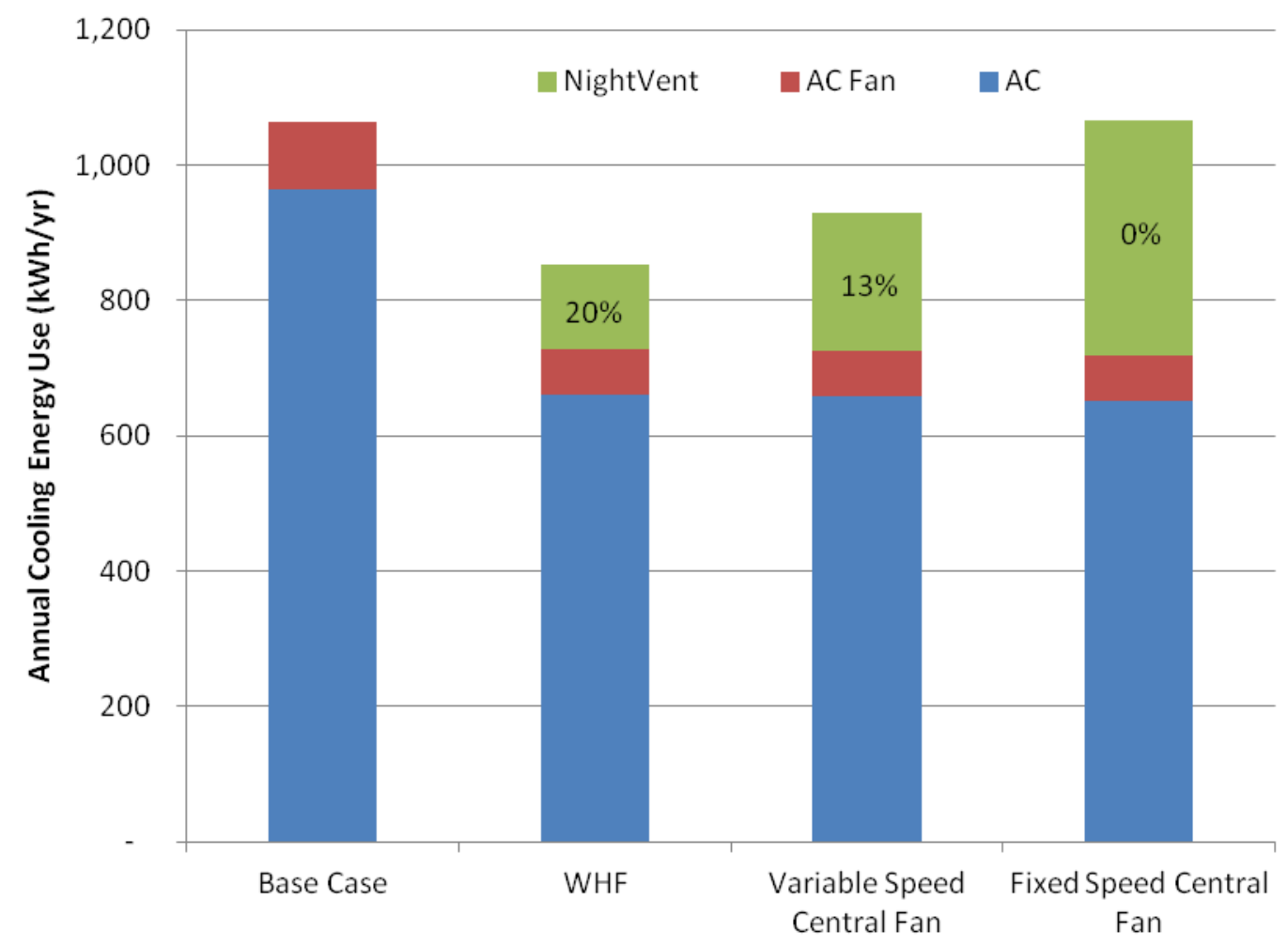

Figure 6: Ventilation cooling system performance comparison and percent energy savings for Sacramento, CA

\section{Substituting Ventilation Cooling for Air Conditioning in Mild Climates}

To estimate the comfort impact of substituting ventilation cooling for air conditioning in mild climates, a variable speed central fan system was simulated in the marine climate of Santa Rosa, California. Results, shown in Table 5, show a significant decrease in cooling energy use for the ventilation cooling scenario relative to air compressor cooling, and a clear improvement in comfort over the "no cooling" case. Minimal improvements to the Benchmark house, such as reduction of east-west windows and summer shading of south windows, combined with ventilation cooling would improve comfort still further.

Table 5: Santa Rosa Cooling Strategy Energy Use and Hours Above Indoor Thermostat Setpoint

\begin{tabular}{|c|c|c|c|c|c|}
\hline Cooling Strategy & $\begin{array}{c}\text { Cooling } \\
\text { Energy Use } \\
(\mathbf{k W h} / \mathbf{y r}) \\
\end{array}$ & $\begin{array}{c}\# \text { of hours } \\
\text { above } 76^{\circ} \mathrm{F}\end{array}$ & $\begin{array}{c}\# \text { of hours } \\
\text { above } 77^{\circ} \mathrm{F}\end{array}$ & $\begin{array}{c}\# \text { of hours } \\
\text { above } 80^{\circ} \mathrm{F}\end{array}$ & $\begin{array}{c}\# \text { of house } \\
\text { above } 81^{\circ} \mathrm{F}\end{array}$ \\
\hline Air Conditioning & 120.5 & 143 & 8 & 0 & 0 \\
\hline $\begin{array}{l}\text { Central Fan } \\
\text { Ventilation Cooling }\end{array}$ & 62.6 & 173 & 92 & 10 & 0 \\
\hline No Cooling & 0 & 226 & 132 & 22 & 9 \\
\hline
\end{tabular}




\subsection{Selection Criteria}

Which system type to install, or whether to install one at all, depends on whether the house is new or existing, the climate, available space for equipment, type of furnace or heat pump, occupant requirements and other factors. First, site-specific climate data should be reviewed based on the criteria outlined in Section 2.3 and Section 2.4 above and, if possible, the occupant interviewed to assess their comfort requirements. Ventilation cooling may not be justified in homes where occupants have the following requirements:

- Daytime cooling setpoint below $72^{\circ} \mathrm{F}$

- Maximum allowable diurnal temperature fluctuations within the home of less than $5^{\circ} \mathrm{F}$

Some guidelines for system type selection are provided below.

- If there is inadequate space for equipment (for example no attic, basement or crawlspace), it is unlikely that either system could be installed without modifications to the home. Both system types will require at least 4' of clearance for the fan or damper. Central fan systems will also require access to outdoor air via a ducted outdoor air intake.

- If the occupants are highly prone to pollen allergies, if home security is a significant issue (as with open windows in one story houses), or occupants are unable or unwilling to manage windows and fan operation, a central fan system would be a better choice.

- If the house does not (or will not) include a furnace or heat pump that is compatible with variable speed central ventilation systems, other alternatives must be considered (fixed speed central fan or whole house fan).

- If the house is in a marine or cold climate (with low cooling requirements) and incorporates basic passive design features, capital costs for equipment will be lower with ventilation cooling than for air conditioning, and in all likelihood reasonable comfort can be maintained.

\section{Whole House Fan}

When selecting a whole house fan, tradeoffs between the two primary styles of fans should be considered. If the ability to quickly cool the house down is desired and noise is not a concern, a propeller style fan is probably a better choice. However, for occupants that would prefer a quieter fan than can be operated throughout the night, an insulated damper style fan would be a better fit. Where appropriate, whole house fans with insulated dampers are preferred as they do not create an uninsulated penetration in the ceiling that increases building heat gain in summer months and heat loss in winter months.

Whole house fans can be controlled by single speed, two-speed, or variable speed motors. Twospeed and variable speed fans offer more flexibility in sizing and satisfying comfort requirements. respectively. These results

\section{PG\&E Night Monitoring \&}

In 2008, Pacific Gas \& ectric commissioned field systems in six new homes near Sacramento. Over the demand savings ranged from $43 \%-67 \%$; however, total energy savings were negligible. For days that reached $92^{\circ} \mathrm{F}$ or higher, average daily cooling and $30.4 \%$ for fixed and variable systems, suggest that modifying control settings to restrict to warmer days would improve savings. Occupants reported high overall satisfaction with the systems. 
Larger homes need higher ventilation rates and larger fans. Whole house fans that are intermittently operated (evening and morning) need to supply higher ventilation rates than smaller systems that are installed to operate throughout the night.

Air changes per hour (ACH) is a metric used by many whole house fan manufactures to identify the size of fan needed. The $\mathrm{ACH}$ refers to the frequency with which the air inside the home is replaced with outdoor air. For example, $20 \mathrm{ACH}$ means that the air inside the home will be replaced with outdoor air 20 times within one hour. $\mathrm{ACH}$ is calculated from the house volume, or the total conditioned floor area times the average ceiling height (see sidebar).

The large propeller style whole house fans are typically installed to provide 10 to $30 \mathrm{ACH}$ while smaller insulated damper style fans deliver less air and are typically sized to provide about 5 air changes per hour. A minimum of $5 \mathrm{ACH}$ should be provided. Table 6 provides example fan sizing for typical house conditioned floor areas (CFA) for $5 \mathrm{ACH}$ and 20 $\mathrm{ACH}$ rates. The required $\mathrm{ACH}$ for acceptable ventilation cooling performance will vary depending on the building envelope efficiency and level of thermal mass.

Table 6: Required Fan Capacities for Desired Air Changes Per Hour

\begin{tabular}{c|c|c}
\hline $\begin{array}{c}\text { House CFA } \\
\text { (8' ceilings) }\end{array}$ & $\begin{array}{c}\text { Fan Capacity } \\
\text { a } \mathbf{5} \text { ACH }\end{array}$ & $\begin{array}{c}\text { Fan Capacity } \\
\text { a } \mathbf{2 0} \mathbf{A C H}\end{array}$ \\
\hline \hline $1,000 \mathrm{sq} \mathrm{ft}$ & $667 \mathrm{cfm}$ & $2,667 \mathrm{cfm}$ \\
\hline $1,500 \mathrm{sq} \mathrm{ft}$ & $1,000 \mathrm{cfm}$ & $4,000 \mathrm{cfm}$ \\
\hline $2,000 \mathrm{sq} \mathrm{ft}$ & $1,333 \mathrm{cfm}$ & $5,333 \mathrm{cfm}$ \\
\hline $2,500 \mathrm{sq} \mathrm{ft}$ & $1,667 \mathrm{cfm}$ & $6,667 \mathrm{cfm}$ \\
\hline $3,000 \mathrm{sq} \mathrm{ft}$ & $2,000 \mathrm{cfm}$ & $8,000 \mathrm{cfm}$ \\
\hline
\end{tabular}

\section{Central Fan System}

Variable speed fan systems are generally preferred over fixed speed systems because energy savings are much greater, and they do a better job of maintaining comfort. The variable speed products also have the potential to provide winter as well as summer fresh air ventilation for maintaining indoor air quality. However, variable speed HVAC system choices are limited to specific manufacturers' furnaces, heat pumps, and air handlers. Due to increased furnace and heat pump product differentiation with respect to motor types and control protocols, choices are becoming more limited, requiring ventilation products to adapt to these changes. Future products may access weather data to determine the optimal operating strategy instead of utilizing predictions that are based on locally monitored temperatures.

Fixed speed central fan systems are compatible with nearly all furnaces and heat pumps, but if not properly controlled can be more expensive to operate than air conditioning alone. Because they continue to ventilate at a fixed rate down to a specific indoor "low limit" temperature setting, they will provide too much cooling during mild weather, or inadequate cooling during hot weather, unless the low limit setting is modified by the homeowner. 
To identify what the optimal airflow rate should be for central fan systems, simulations were completed using a low-load $1,860 \mathrm{ft}^{2}$ house modeled in a hot-dry climate. Figure 7 illustrates the tradeoff between compressor cooling and fan energy for this house. Increasing the airflow rate results in overall cooling savings up to a point at which the combination of fan and compressor energy begins to increase again. The "sweet spot" in this figure reflects a system designed to 4.5 $\mathrm{ACH}$ (assuming 8' ceilings), or $0.6 \mathrm{cfm}$ per square foot of conditioned floor area. This "rule of thumb" sizing of $4.5 \mathrm{ACH}$ or $0.6 \mathrm{cfm}$ per ton should be adequate for most central fan system applications. This will vary based on house cooling load and thermal mass characteristics. However, the relationship between airflow and energy use is fairly flat and therefore energy savings should still be realized even if the system is slightly undersized or oversized.

\section{Integrated Ventilation Cooling}

Field monitoring was conducted under Building America in 2009 by CARB (DEG). Central fan ventilation systems were installed and monitored in four houses in California and Nevada representing Hot-Dry, Marine and Cold climate regions. It was found that ventilation cooling can potentially displace compressor based air conditioning in Cold and Marine climates with hot summers, and air conditioning use can be significantly reduced in Hot-Dry climates.

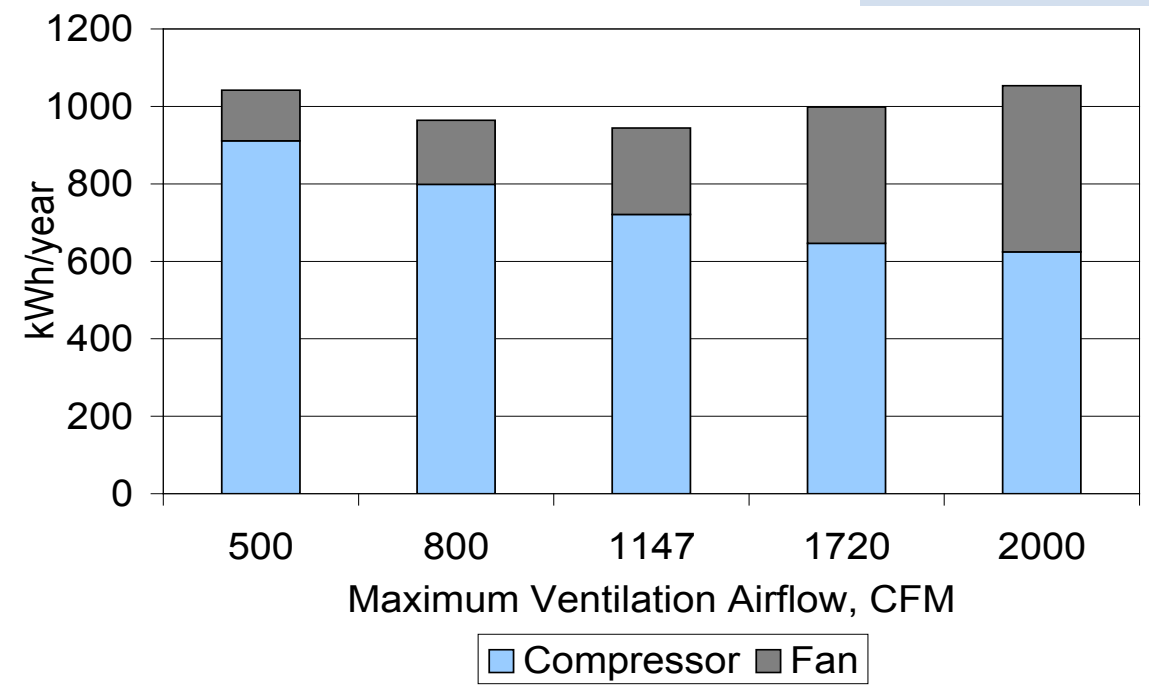

Figure 7: Cooling energy use vs. maximum airflow for an $1,860 \mathrm{ft}^{2}$ house in a hot-dry climate

Furnaces and heat pump systems are usually sized to provide sufficient air to meet the design heating and cooling load, but this sizing may not be compatible with ventilation cooling sizing. Using the 1,860 $\mathrm{ft}^{2}$ house as an example, if it is very well designed it might only require a 2-ton air conditioner that delivers $800 \mathrm{cfm}$, resulting in an air change rate of only $3.2 \mathrm{ACH}$. Using the 4.5 ACH rule, the design ventilation cooling airflow rate would be approximately $1,100 \mathrm{cfm}$. In this case the furnace or air handler fan, indoor cooling coil (if used), and ducting would need to be upsized to accommodate the additional airflow. This "rule of thumb" sizing of $4.5 \mathrm{ACH}$ or 0.6 cfm per ton is appropriate for most applications, but indoor components should not be oversized by more than one ton. Upsizing the indoor components without increasing the outdoor condensing unit will tend to improve air conditioning system performance. 


\section{Section 3:Measure Implementation Details}

All installation and retrofit work should be conducted by licensed professionals with appropriate contractor licenses. It is important that all installations follow local and national code and manufacturer provided installation instructions. Installers should familiarize themselves with local codes and identify any requirements that may affect the installation.

Special attention should be paid whenever retrofit work is to be conducted, as existing homes may pose unique combustion safety issues. In particular, whole house fans may create combustion safety hazards due to house depressurization and/or pressurization of attic or other spaces. Home inspections must insure that combustion appliances (water heaters and furnaces) in homes with whole house fans are direct-vented to the exterior and do not obtain combustion air from the house interior or attic spaces.

Also, ventilation system installation criteria should be reviewed and compared to site conditions. A pre-installation inspection should determine the following information for the equipment under consideration:

- Is there adequate space for the proposed equipment and adequate access for maintenance of controls and other components?

- Is the proposed equipment compatible with existing or planned mechanical systems?

- Is there an adequate source of power for the equipment?

- Are air passages (for whole house fans) and ducts (for integrated systems) sized appropriately?

- What is the location and size of the openings into the house and to the exterior, and does the builder/owner understand the visual and operational considerations related to required grilles and dampers?

- Are there security issues related to window operation with a whole house fan and how might they be addressed? 


\subsection{Field Inspection Combustion Appliances}

This risk is specific to whole house fans, not central fan systems that employ balanced ventilation or slight pressurization of interior spaces. Improper operation of whole house fans can result in significant house depressurization, which can result in back drafting of combustion gases from appliances such as gas water heaters, furnaces, and fireplaces or wood stoves, particularly those that use indoor air as a source of combustion air. A whole house fan should never be installed when a gas appliance with a standing pilot is located in the house or attic, or a gas appliance receives its combustion air from within the home or attic. Furnaces and water heaters that are located within the conditioned space should always be "direct vent", meaning they are isolated from the interior of the home by providing combustion air to the burner directly from outside and by exhausting flue gases directly to outside. Many local codes prohibit the installation of a whole house fan in houses with gas furnaces without the installation of a control that prohibits simultaneous use of the furnace and fan. If a gas water heater or furnace located in an unconditioned basement or garage is atmospherically vented or has a standing pilot, it is recommended that basement and garage doors are properly weatherstripped and a combustion appliance safety (CAS) test be performed to make sure that combustion gases are not pulled into the living space during operation of the whole house fan. Figure 8 provides a method for determining safe conditions for whole house fan installation. While the fan is operating, windows must be open such that the pressure inside the house is not excessively low.

\section{Barriers to Implementation}

The primary barriers to implementation of whole house fans include cost, compromised security (from open windows), and noise. Conditions in some homes, for example those with flat roofs and no attic, make installation very difficult and/or expensive. Outdoor noise is attenuated by open windows, and the larger style fans can also tend to be noisy. The smaller shuttered fans are quieter but move less air. Susceptibility to allergic reactions from dust and pollens may also be a barrier for whole house fans.

Cost is the primary barrier for central fan systems. Constant airflow systems are available from at least one manufacturer and applicable to any furnace or heat pump that uses conventional $24 \mathrm{VAC}$ controls. There is currently one manufacturer of variable airflow systems, which also produces compatible air handlers with hydronic heat coils. However, the variable airflow system is only compatible with one major manufacturer's furnace and heat pump, which creates a market barrier. Modifications to this product and/or alignment with a major manufacturer's product line could make it more widely accessible. 


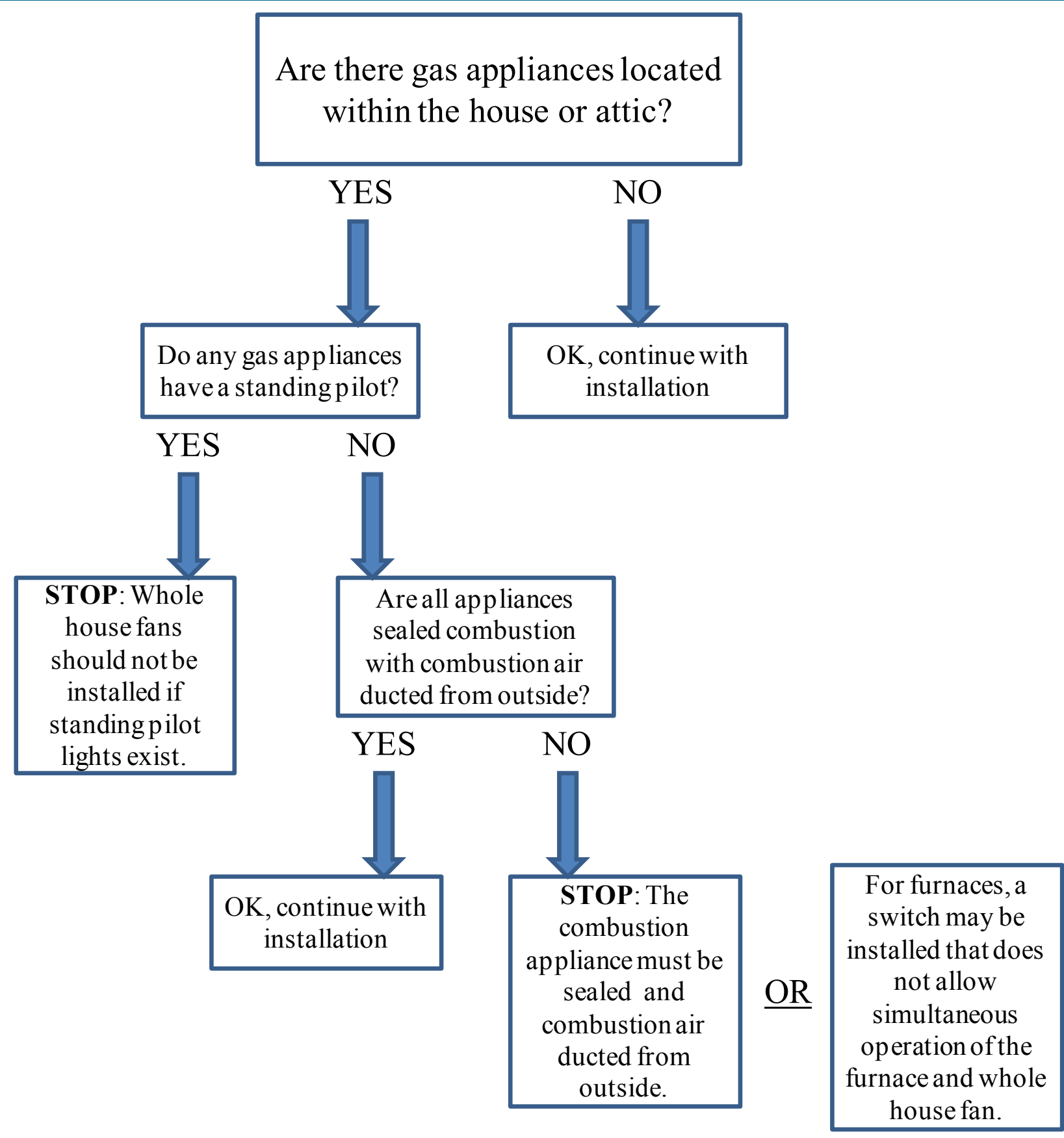

Figure 8: Diagram of safety check process for whole house fan 


\subsection{Site Preparation}

\section{Attic Ventilation}

Most ventilation cooling systems vent air directly to the attic space. This relief air eventually must find its way outside.

Providing sufficient attic ventilation is important so that systems perform as designed. Whole house fan manufacturer specifications will often provide the required attic net free vent area (NFVA) for their fans. The NFVA is the total unobstructed open area through which air can exit the attic. A commonly used guideline is that one square foot of ventilation area should be provided for each $750 \mathrm{cfm}$ of fan capacity. For central fan systems this will be met through compliance with building code ventilation requirements, which typically call for a NFVA of no less than 1/150 or $1 / 300$ of the attic area (ICC, 2012). However, in multiple story homes with small footprints that install large propeller style whole house fans, it is important to verify the available NFVA.

Use Table 7 to calculate the necessary attic ventilation area based on fan capacity.

Table 7: Minimum Attic Net free Ventilation Area Based on Fan Capacity

\begin{tabular}{c|c}
\hline $\begin{array}{c}\text { Maximum } \\
\text { Fan Capacity }\end{array}$ & $\begin{array}{c}\text { Minimum } \\
\text { Attic NFVA }\end{array}$ \\
\hline \hline $750 \mathrm{cfm}$ & $1.0 \mathrm{sq} \mathrm{ft}$ \\
\hline $1,000 \mathrm{cfm}$ & $1.3 \mathrm{sq} \mathrm{ft}$ \\
$1,500 \mathrm{cfm}$ & $2.0 \mathrm{sq} \mathrm{ft}$ \\
\hline $2,000 \mathrm{cfm}$ & $2.7 \mathrm{sq} \mathrm{ft}$ \\
\hline $2,500 \mathrm{cfm}$ & $3,3 \mathrm{sq} \mathrm{ft}$ \\
\hline $3,000 \mathrm{cfm}$ & $4.0 \mathrm{sq} \mathrm{ft}$ \\
\hline $3,500 \mathrm{cfm}$ & $4.7 \mathrm{sq} \mathrm{ft}$ \\
\hline $4,000 \mathrm{cfm}$ & $5.3 \mathrm{sq} \mathrm{ft}$ \\
\hline $4,500 \mathrm{cfm}$ & $6.0 \mathrm{sq} \mathrm{ft}$ \\
\hline $5,000 \mathrm{cfm}$ & $6.7 \mathrm{sq} \mathrm{ft}$ \\
\hline $5,500 \mathrm{cfm}$ & $7.3 \mathrm{sq} \mathrm{ft}$ \\
\hline $6,000 \mathrm{cfm}$ & $8.0 \mathrm{sq} \mathrm{ft}$ \\
\hline
\end{tabular}

Effectiveness of attic vents is diminished through the use of screens and louvers. Many manufacturers will list the "net free area" on their products. Use this reduced area when possible in calculating total available attic ventilation.

When equipment and return ductwork is located in the crawlspace, it may be possible to vent directly to this space as well. Requirements for adequate ventilation area would be similar. For homes without ventilated attics or with equipment located in basements or conditioned mechanical spaces, exhaust air can be directly ducted to outside. Depending on location and design of the system, the exhaust duct may require a motorized damper to open on operation and the exhaust duct needs to be properly sized for the design airflow. 


\section{Building Sealing}

All penetrations between the house and unconditioned space should be sealed with caulking, tape, gaskets or another appropriate method. Since most ventilation systems exhaust relief air into the attic, sealing between the house and the attic is especially important since operation effectively pressurizes the attic space, allowing air to easily leak back into the house through unintentional gaps. For whole house fan installations, ensure proper sealing and weatherstipping of doors between the living space and attached garages or unconditioned basements.

\subsection{Installation Procedure - Whole House Fans}

\section{Location}

A whole house fan should be located horizontally at the ceiling level as close as possible to the center of the house. In multiple story homes it can be installed at the second floor ceiling near the stairway or at an indoor balcony. When necessary some fans can be installed vertically in exterior walls or knee walls.

\section{Step-by-Step Installation}

The following information is provided as a general guide. Always follow manufacturers' installation procedures, which take precedence over these instructions.

Most whole house fans are designed to be installed in either standard 16" or 24" o.c. ceiling joist spacing. The following instructions outline the general installation process for a typical whole house fan ceiling installation. It is important to follow manufacturer supplied installation instructions as requirements may vary by product.

1. Prior to installation, verify that there is adequate attic venting for whole house fan relief and that there is a circuit available for connecting power to the fan.

2. Clear the attic area of insulation and debris to prepare for installation. For new construction, install the fan prior to blowing attic insulation. Make sure there is adequate space in the proposed location for the fan to fit and, if the fan has insulated shutters, verify that the shutters will not encounter obstructions such as truss members when they open. Also verify that there are no obstructions to the air path from the attic to outdoors.

3. Frame out the ceiling joists (or lower truss members) to the size required by the fan manufacturer. The installer will need framing material to match the depth of the ceiling joists. For example, if the joists are 2" x 8", use 2" x 8" stock for the frame-out as shown in Figure 9. DO NOT CUT ANY EXISTING JOISTS OR TRUSSES. 


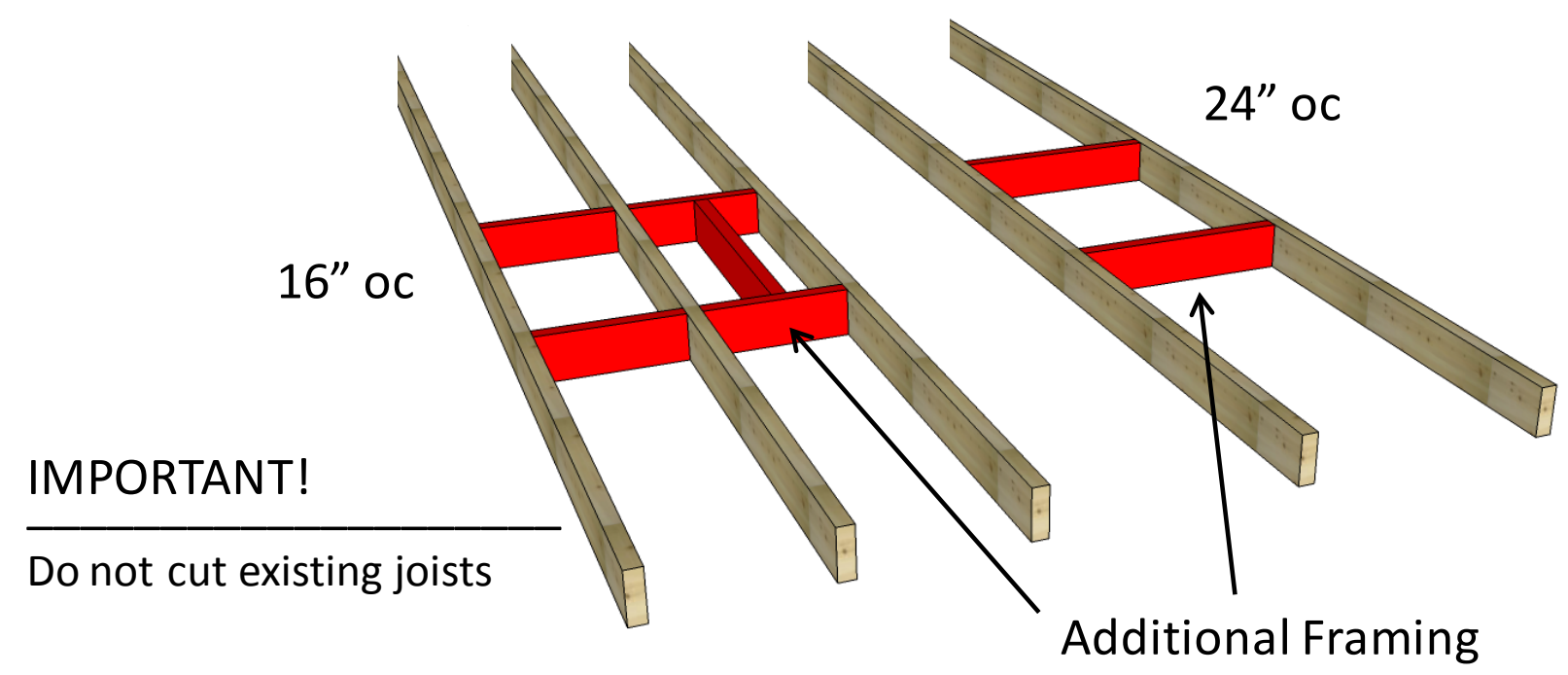

Figure 9: Joist framing

4. Cut out the drywall within the framed opening, making certain not to cut an opening larger than required for the fan, as the louver frame or grill will not cover the cut-out. Some manufacturers provide templates for this purpose.

5. Proper sealing of all joints and seams is important to ensure the whole house fan is only drawing air from inside the house and to minimize air leakage between the house and the attic when the fan is not operating. Seal the joints between the frame-out and the ceiling drywall using spray foam or caulk. Inspect the fan box itself and seal any noticeable gaps. Use foam weather stripping or spray foam to create a seal between the fan box and the frameout and drywall.

6. Position the fan box on or in the frame-out as required and secure it in accordance with the manufacturer's instructions.

7. Wire the whole house fan and controls according to the manufacturer's instructions. It is recommended that all electrical work be completed by a licensed electrician.

8. At the ceiling below the fan install the louver frame or grille. In the attic, the area surrounding the fan should be boxed in using plywood or other appropriate material to prevent loose fill insulation from falling into the fan. This material may be part of the fan installation kit.

For whole house fans that do not have insulated shutters, an attic-side fan cover should be provided to insulate between the attic and the house when the fan is not in use (especially in winter). A cover could be made using rigid duct board insulation or a vinyl water heater blanket. A tag located at the underside of the fan could be used as a reminder that the cover is in place to avoid damage when the fan is turned on.

System Setup and Verification: Operate the fan at its different speeds using the installed wall control or remote. If it is equipped with insulated shutters, verify that they open when the fan is 
on. If it is equipped with a barometric (air pressure operated) damper, verify that the damper does not bind or stick and that it opens completely when the fan is turned on and closes fully when the fan is off. For systems that include an interlock between the whole house fan and a gas furnace, verify operation of the interlock specifically that if the combustion appliance is on when whole house fan operation is initiated, the combustion appliance turns off before the fan turns on.

\subsection{Operation and Maintenance - Whole House Fans Operation}

Whole house fans should never be operated without opening of windows to provide adequate supply air flow. If energy savings are to be realized, occupants must be aware of the indoor and outdoor temperature conditions and be prepared to operate the fan and windows when temperature conditions are favorable, for example $3^{\circ} \mathrm{F}-5^{\circ} \mathrm{F}$ cooler outdoors than indoors. Monitoring these temperatures can be difficult on warm nights when the outdoor temperature does not fall until late at night. Two-speed or variable speed fans will cool the house down more quickly if turned on high. However, fans operate more efficiently at low speeds, and long continuous operation at low speed will provide better energy savings as opposed to shorter periods of high-speed operation. For maximum cooling benefit, the fan should be operated throughout the night until the inside and outside temperatures equilibrate, or until the indoor temperature is too low to be comfortable. This may not feasible with large propeller style fans with very high airflows that are quite noisy. It may require a full night of operation for the cooling to penetrate the floor, walls, and other mass elements sufficiently that they will be able to effectively reduce next day's air conditioner operation. Whole house fans can just as easily bring in warm air and increase cooling energy use if the fan and windows are not operated correctly.

It is recommended that there be a minimum of four square feet of open window or door area for each 1,000 cfm of fan airflow. This should insure a maximum pressure difference between indoors and outdoors of 25 Pascal (0.1"). At this pressure difference, it would require a maximum force of about $5 \mathrm{lbs}$ to open a $3 \mathrm{ft}$ wide door, which is manageable by most people (Springer, 2004). Interior doors to all rooms that have open windows should be kept open. Use Table 8 below to calculate the necessary inlet area based on fan capacity. 
Table 8: Minimum Inlet Area Based on Fan Capacity

\begin{tabular}{c|c}
\hline $\begin{array}{c}\text { Maximum Fan } \\
\text { Capacity }\end{array}$ & $\begin{array}{c}\text { Minimum Inlet } \\
\text { Area }^{5}\end{array}$ \\
\hline $750 \mathrm{cfm}$ & $3 \mathrm{sq} \mathrm{ft}$ \\
\hline $1,000 \mathrm{cfm}$ & $4 \mathrm{sq} \mathrm{ft}$ \\
\hline $1,500 \mathrm{cfm}$ & $6 \mathrm{sq} \mathrm{ft}$ \\
\hline $2,000 \mathrm{cfm}$ & $8 \mathrm{sq} \mathrm{ft}$ \\
\hline $2,500 \mathrm{cfm}$ & $10 \mathrm{sq} \mathrm{ft}$ \\
\hline $3,000 \mathrm{cfm}$ & $12 \mathrm{sq} \mathrm{ft}$ \\
\hline $3,500 \mathrm{~cm}$ & $14 \mathrm{sq} \mathrm{ft}$ \\
\hline $4,000 \mathrm{~cm}$ & $16 \mathrm{sq} \mathrm{ft}$ \\
\hline $4,500 \mathrm{cfm}$ & $18 \mathrm{sq} \mathrm{ft}$ \\
\hline $5,000 \mathrm{cfm}$ & $20 \mathrm{sq} \mathrm{ft}$ \\
\hline $5,500 \mathrm{cfm}$ & $22 \mathrm{sq} \mathrm{ft}$ \\
\hline $6,000 \mathrm{cfm}$ & $24 \mathrm{sq} \mathrm{ft}$ \\
\hline
\end{tabular}

\section{Maintenance}

Except for covering the fan with insulation during winter (for fans without shutters), no maintenance is required. Fan motor bearings are sealed and require no lubrication.

\subsection{Installation Procedures - Central Fan Systems}

\section{Outside Air Damper}

Central fan systems utilize a single two-position damper which switches between recirculation and outdoor air modes as shown in Figure 10. The use of dampers that are typically used for zone control and louver type dampers are not recommended because they do not seal adequately and compromise the air tightness of the duct system.

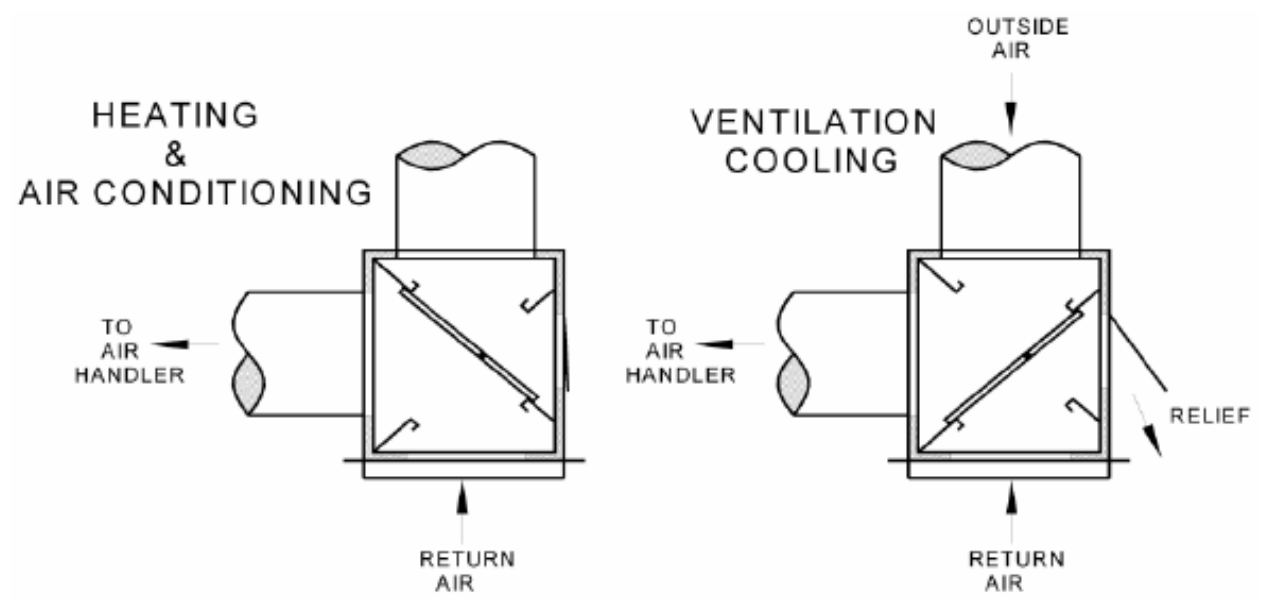

Figure 10: Outside air damper position relative to operational mode

When in ventilation cooling mode, the damper actuator rotates so that outside air is drawn in by the air handler or furnace, positively pressurizing the house. Indoor air is then relieved through the return air grille. A secondary mechanical damper or barometric relief allows air to flow from

\footnotetext{
${ }^{5}$ PG\&E, Technical Sheet: Whole House Fans.
} 
the damper enclosure into the attic. Some dampers must be continuously powered in order to seal properly, in which case duct leakage should only be tested while the damper is powered. The system should be designed and tested so that the house does not experience a pressure difference greater than 25 Pascal compared to outdoors (Springer, 2004).

\section{Outdoor Air Intake Location}

Outside air must be ducted from an intake location to the damper as shown in Figure 10. Refer to Table 9 for required vent intake minimum free area and minimum outside air duct size. Use a gable-mounted louver (Figure 11), dormer vents, a vent in an overhanging soffit, a roof-mounted dormer vent or a false chimney with suitable vent cap for the outside air intake. Multiple outside air intakes may be required, depending on the required ventilation airflow and free area of the louver/vent. Ensure all intakes are at least 10' away from any exhaust outlet such as from a bathroom, dryer, or flue (refer to local code requirements for location of fresh air intakes).

Table 9: Outdoor Air and Return Duct Sizing Recommendations

\begin{tabular}{c|c|c}
\hline $\begin{array}{c}\text { Recommended } \\
\text { Maximum } \\
\text { Ventilation Airflow }\end{array}$ & $\begin{array}{c}\text { Minimum } \\
\text { Duct Size }\end{array}$ & $\begin{array}{c}\text { Vent Intake Minimum } \\
\text { Free Area, } \mathbf{f t}^{2}\end{array}$ \\
\hline \hline $800 \mathrm{cfm}$ & $14^{\prime \prime}$ & 1.00 \\
\hline $1000 \mathrm{cfm}$ & $16^{\prime \prime}$ & 1.25 \\
\hline $1300 \mathrm{cfm}$ & $18^{\prime \prime}$ & 1.63 \\
\hline $1600 \mathrm{cfm}$ & $20^{\prime \prime}$ & 2.00 \\
\hline $1800 \mathrm{cfm}$ & $20^{\prime \prime}$ & 2.25 \\
\hline
\end{tabular}

\section{Air Handler, Cooling Coil, and Condenser Sizing}

Air conditioners should be sized and selected in accordance with ACCA Manuals J and S. The Manual $\mathrm{J}$ sizing procedure takes into account house characteristics including orientation, insulation levels, windows, and internal gains, as well as duct location and quality to estimate the cooling capacity necessary on a "design" summer day.

An exception to Manual $\mathrm{J}$ sizing is that, if the airflow required for ventilation cooling exceeds the airflow for air conditioning (typically $400 \mathrm{cfm}$ per ton in dry climates), larger indoor cooling coils should be installed to minimize pressure drop across the coil. Cooling coils should not add more than 0.25 " of pressure loss at the maximum ventilation cooling airflow rate (Wilcox, 2007). The larger coil will also result in improved air

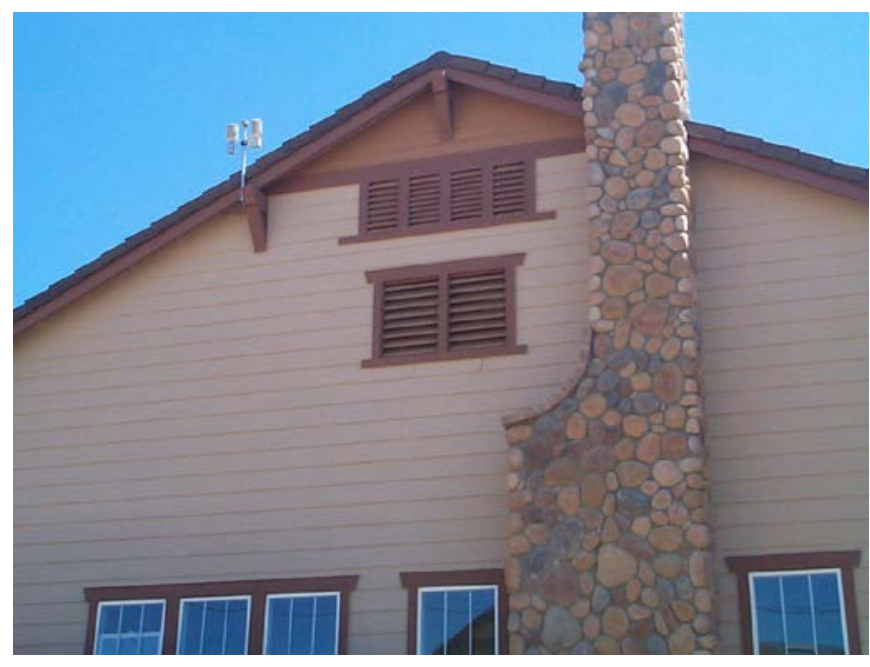

Figure 11: For this house the upper set of louvers is for the outside air intake; the lower pair is for attic ventilation. conditioner performance. Delivered ventilation airflow may need to be reduced based on indoor coil size. Indoor coils should not be sized more than one ton above the outdoor unit. 
For variable speed systems consult the manufacturer for approved furnaces/air handlers that are compatible with the system's controls.

\section{Duct Design}

Because central fan systems rely on the HVAC distribution system, proper sizing of the ductwork is essential. Undersized ducts create high pressure losses, resulting in reduced airflows and high fan energy use. ACCA Manual D duct sizing procedures should be followed to ensure correct duct sizing. Especially in low-load homes, the design ventilation cooling airflow (at least $4 \mathrm{ACH}$ or $0.6 \mathrm{cfm}$ per square foot of conditioned space) may be higher than heating and cooling design airflows. If the discrepancy is less than one ton, the duct system, along with the indoor coil (see above), should be sized to handle the air volume required for ventilation cooling instead of for conventional cooling. In retrofit applications, this may require replacement of the duct system. The designer should try to minimize system pressure drop as much as possible by shortening duct runs and limiting bends and connections. Recommended minimum sizes for outside air ducts are indicated in Table 9.

If the house requires two or more zones, do not use bypass dampers, but instead oversize ducts and/or select one or more registers that will be used to discharge excess air into a central zone.

\section{Relief Air}

The simplest means of handling relief air is to exhaust it directly to the attic space. Of course this is only appropriate when the return ductwork and ventilation cooling damper is located within the attic. Alternative configurations are an option with relief air ducted directly to outdoors. This is most appropriate for houses with unvented attics, space constraints, or return ductwork in basements or mechanical closets.

\section{Systems Requiring Multiple Returns}

Central fan systems distribute air to every room, and for the system to be effective, the air must have a path to the return grille and outdoors. To assure proper ventilation cooling performance as well as performance of heating and cooling systems, dedicated returns, "jump ducts" or transfer grilles should be installed to provide return/relief air to any spaces that can be isolated from the return air path by closed doors. This may apply to any space with more than $100 \mathrm{cfm}$ of supply air (undercut doors can usually supply up to $100 \mathrm{cfm}$ ).

It is good practice to provide separate return air paths from large rooms such as bedrooms to prevent pressure imbalances between rooms when doors are closed. However, if returns are installed downstream of the vent damper, outside air will be diluted with indoor return air while the system is in ventilation cooling mode, significantly reducing the ventilation cooling effectiveness. Methods to prevent this dilution vary by manufacturer, and include:

- Option 1: Installing a damper in the secondary return to close it off during ventilation cooling operation

- Option 2: Substituting jump ducts for returns

- Option 3: Using a damper that is designed to accept a second return air duct. 

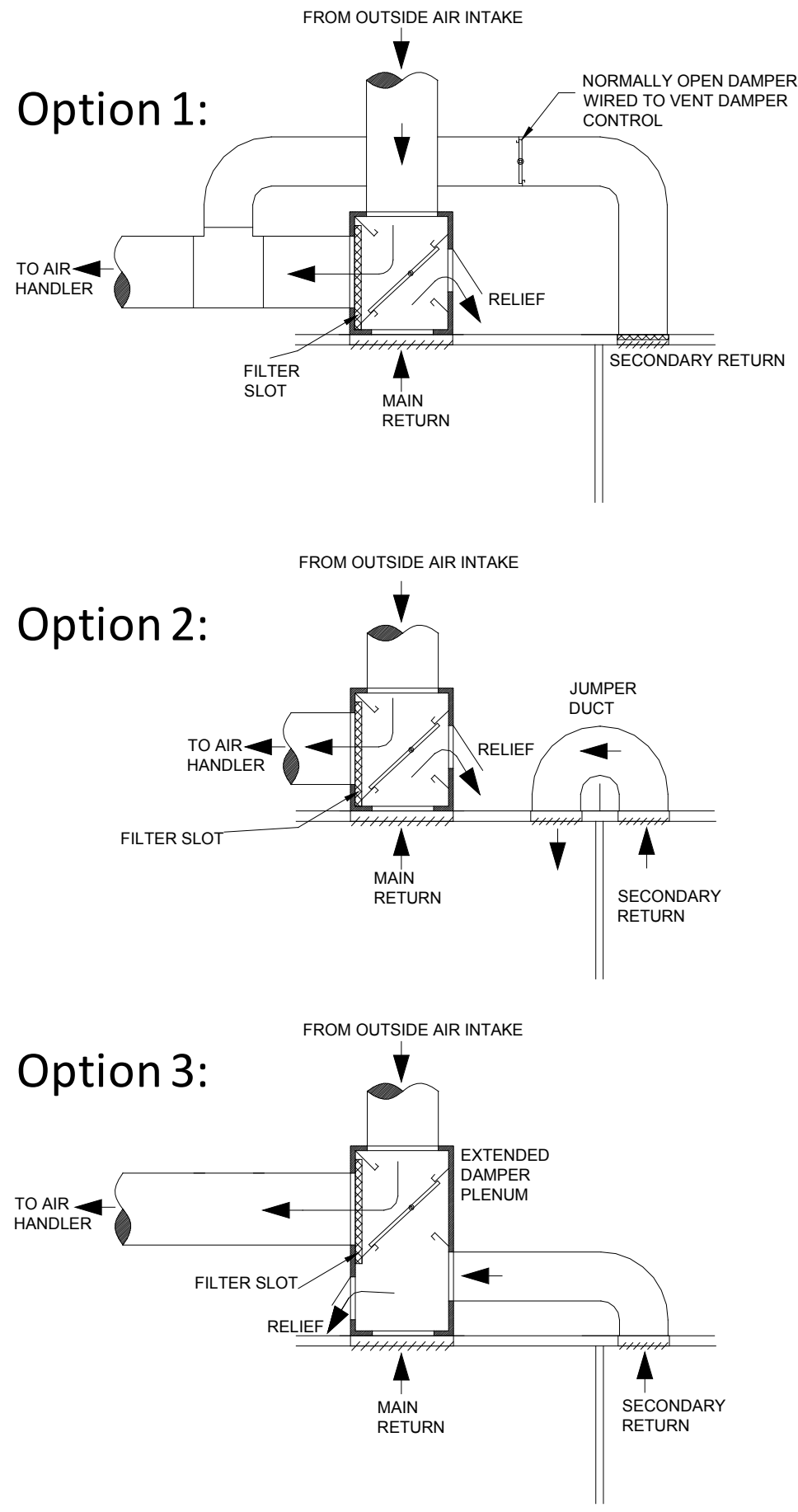

Figure 12: Multiple return air path configurations 


\section{Step-by-Step Installation}

The following instructions outline the general installation process for typical central fan systems. It is important to follow manufacturer-supplied installation instructions as requirements vary by product. Contractor training in the particular product being installed is highly recommended.

Outside Air Damper Installation: The outside air damper (vent damper) is typically installed above the primary return air grille. Access to the filter slot in the damper is through the return grille, which must be of the hinged type. Refer to the manufacturer's instructions for installation details. The damper must be in a location that is accessible for maintenance. Make duct connections between the damper and the furnace/air handler and outside air intake. The duct from the outside air intake should be sized so that it adds no more than 0.05 " of static pressure at the maximum ventilation airflow rate. Seal all connections in accordance with IECC 2003803.2.8.

If the damper is installed in a non-vented attic, the relief opening as well as the outside air intake must be ducted to outdoors. The relief duct can be sized for $75 \%$ of the maximum system airflow since exhaust fan openings and house leakage can typically carry the remaining $25 \%$ without over pressurizing the house.

Some dampers utilize rough-in boxes that allow working parts to be removed to avoid damage during construction. For other damper types, the bottom opening should be covered with cardboard to prevent overspray by texture and paint. Never attempt to force open the damper as this will cause damage to the linkage.

Controller: Refer to manufacturers' instructions for completing wiring connections between the controller and the furnace/air handler, the thermostat, damper, outdoor temperature sensor, and other components. Controllers may be provided as part of the air handler or separately.

Outdoor Temperature Sensor: Proper placement of the outdoor temperature sensor is very important to assure proper control operation and temperature readings. Always locate it where it is shaded from direct sunlight, preferably on the north side of the building or under an overhang. A preferred location is on the eastern side of a north facing wall where it won't receive exposure from afternoon sun. Avoid placement above a roof or adjacent to a west or northwest facing wall, or anywhere where hot air might collect. If multiple ventilation cooling systems are installed, always position the outdoor sensors in the same location. Ensure the sensor is not located near any exhaust outlet such as from a bathroom, dryer, or flue. Avoid locating above or near air conditioning condensing unit.

Temperature sensors should be calibrated as part of the commissioning process. To calibrate the sensors, use an accurate handheld digital thermometer to measure air temperature in close proximity to the thermostat and the outdoor temperature sensor. Be sure to allow adequate time for the handheld thermometer to equilibrate to ambient temperatures before taking readings.

System Setup and Verification: Depending on the system type, airflow may be set at the air handler/furnace using dipswitch or tap settings, or at the thermostat. Refer to manufacturers' instructions for establishing airflow settings and other control parameters. It is useful to document control settings in the event they are inadvertently changed or lost. 
Install an air filter of the correct size in the slot provided such that it filters both the return and outdoor air streams.

Using manual control features of the system, operate the damper to insure that it re-circulates indoor air in heating or air conditioning mode, and draws outside air in ventilation mode. At this point of the installation, it is recommended that a duct pressurization test be conducted to measure total (duct and damper) air leakage. Damper leakage can be determined by taping off the outside air opening, repeating the pressurization test, and subtracting the second leakage rate from the first leakage rate. The damper alone should not contribute more than $2 \%$ of total $6 \%$ leakage (as a percent of maximum airflow).

It is also recommended that airflow be tested using an airflow metering plate or flow hood. Due to system restrictions imposed by the ductwork and other components, relying on the tap setting specifications is not an accurate way of verifying correct airflow.

\subsection{Operation and Maintenance - Central Fan Systems Operation}

Follow manufacturer-supplied instructions for thermostat operation. The installer should program the thermostat including the ventilation cooling setpoint and offsets as appropriate for the system and the occupants' comfort requirements.

\section{Maintenance}

The air filter should be regularly replaced every 1-3 months of operation. There is no additional maintenance necessary beyond that that is normally required for a ducted heating/cooling system.

\section{IMPORTANT}

Outdoor Air Filter Placement Most systems have specific filter slots, often vertical, to filter both return air and outdoor air. Follow manufacturer guidelines for filter placement and DO NOT place filters in the return grille where it will only filter return air. 


\section{Attachment A: Prescriptive Measure Checklist}

Whole House Fans

\begin{tabular}{|c|c|}
\hline$\frac{\text { Installation Procedure Guidelines for }}{\text { Whole House Fans }}$ & Completed? \\
\hline \multicolumn{2}{|l|}{ 1. Field Inspection } \\
\hline 1.1 Location meets climate requirements for ventilation cooling & $\square$ \\
\hline \multicolumn{2}{|l|}{ 1.2 Whole house fan selection } \\
\hline 1.2.1 Fan capacity sized correctly based on house volume and design air changes per hour & $\square$ \\
\hline Fan Capacity (cfm): & \\
\hline \multicolumn{2}{|l|}{1.3 Attic } \\
\hline 1.3.1 Gaps and seams caulked and sealed between attic and conditioned space & $\square$ \\
\hline 1.3.2 Adequate ventilation provided? $1 \mathrm{sq} \mathrm{ft}$ for each $750 \mathrm{cfm}$ of fan capacity & $\square$ \\
\hline \multicolumn{2}{|l|}{ 2. System Design } \\
\hline \multicolumn{2}{|l|}{ 2.1 Combustion safety } \\
\hline $\begin{array}{l}\text { 2.1.1 All combustion appliances within the home are sealed combustion or switched such } \\
\text { that they will not operate simultaneously with the WHF }\end{array}$ & $\square$ \\
\hline 2.1.2 No combustion appliances have standing pilot lights & $\square$ \\
\hline \multicolumn{2}{|l|}{ 2.2 Fresh air opening } \\
\hline $\begin{array}{l}\text { 2.2.1 Post minimum inlet area requirements by fan switch. } 4 \mathrm{sq} \mathrm{ft} \text { for each } 1,000 \mathrm{cfm} \text { of fan } \\
\text { capacity }\end{array}$ & $\square$ \\
\hline \multicolumn{2}{|l|}{ 3. Installation } \\
\hline \multicolumn{2}{|l|}{ 3.1 Infiltration Reduction } \\
\hline 3.1.1 Cracks and seams between joists and ceiling sealed & $\square$ \\
\hline 3.1.2 Fan box inspected for leaks and, if necessary, sealed & $\square$ \\
\hline 3.1.3 Fan box sealed to the truss frame & $\square$ \\
\hline 3.2 Switch or control installed at wall and wired to fan & $\square$ \\
\hline 3.3 Fan is protected from attic debris such as blown insulation & $\square$ \\
\hline 3.4 Fan either has insulated dampers or an insulated cover for use during the winter & $\square$ \\
\hline \multicolumn{2}{|l|}{ 4. Verification and Operation } \\
\hline \multicolumn{2}{|l|}{ 4.1 Visual verification of correct operation } \\
\hline 4.1.1 Barometric louvers do not bind or stick & $\square$ \\
\hline 4.1.2 Attic side dampers open and close & $\square$ \\
\hline \multicolumn{2}{|l|}{ 4.1.3 Variable speed controls modulate fan airflow } \\
\hline 4.2 Verification of interlock between fan \& combustion appliances (if installed) & $\square$ \\
\hline 4.3 O\&M manual provided to occupant & $\square$ \\
\hline
\end{tabular}




\section{Central Fan Systems}

\begin{tabular}{|c|c|}
\hline $\begin{array}{l}\text { Installation Procedure Guidelines for } \\
\text { Central Fan Ventilation Cooling System }\end{array}$ & Completed? \\
\hline \multicolumn{2}{|l|}{ 1. Field Inspection } \\
\hline 1.1 Location meets climate requirements for ventilation cooling & $\square$ \\
\hline \multicolumn{2}{|l|}{ 1.2 Fan selection } \\
\hline 1.2.1 Fan capacity sized correctly based on house volume and design $\mathrm{ACH}$ & $\square$ \\
\hline Fan Capacity $(\mathrm{cfm})$ : & \\
\hline \multicolumn{2}{|l|}{ 1.3 Attic } \\
\hline 1.3.1 Gaps and seams caulked and sealed between attic and conditioned space & $\square$ \\
\hline 1.3.2 Adequate ventilation provided? $1 \mathrm{sq} \mathrm{ft}$ for each $750 \mathrm{cfm}$ of fan capacity & $\square$ \\
\hline \multicolumn{2}{|l|}{ 2. System Design } \\
\hline \multicolumn{2}{|l|}{ 2.1 Equipment and duct right sizing } \\
\hline 2.1.1 Manual J \& S completed & $\square$ \\
\hline 2.1.2 Evaporator coil oversized & $\square$ \\
\hline 2.1.3 Manual D completed & $\square$ \\
\hline \multicolumn{2}{|l|}{ 2.2 Outside air } \\
\hline 2.2.1 Outdoor air duct size: & $\square$ \\
\hline 2.2.2 Intake vent sized properly and located $10^{\prime}$ away from any exhaust & $\square$ \\
\hline 2.3 Return or relief air provided in closeable spaces with greater than $100 \mathrm{cfm}$ supply air & $\square$ \\
\hline 2.4 Multiple returns properly ducted to damper or alternative relief installed & $\square$ \\
\hline \multicolumn{2}{|l|}{ 3. Installation } \\
\hline 3.1 Outdoor air temperature sensor installed in a shaded area and properly wired & $\square$ \\
\hline \multicolumn{2}{|l|}{ 3.2 Damper } \\
\hline 3.2.1 Damper installed in correct orientation in rough-in box & $\square$ \\
\hline 3.2.2 Damper motor wired to controller & $\square$ \\
\hline 3.2.3 All ducting installed properly and connections sealed & $\square$ \\
\hline \multicolumn{2}{|l|}{ 3.3 Thermostat } \\
\hline 3.3.1 Properly secured to wall and wired to controller & $\square$ \\
\hline 3.3.2 Programming complete & $\square$ \\
\hline 3.4 Sensors calibrated & $\square$ \\
\hline 3.5 Filter installed in correct location to filter both outside and return air & $\square$ \\
\hline \multicolumn{2}{|l|}{ 4. Verification and Operation } \\
\hline \multicolumn{2}{|l|}{ 4.1 Visual verification of correct operation } \\
\hline 4.1.1 Damper opens and closes correctly & $\square$ \\
\hline 4.1.2 System responds properly to user input to thermostat & $\square$ \\
\hline 4.2 System airflow tested $\quad$ Airflow $(\mathrm{cfm})$ : & $\square$ \\
\hline 4.3 O\&M manual provided to occupant & $\square$ \\
\hline
\end{tabular}




\section{Attachment B: Airflow and Fan Efficacy}

The data in Figure 13 is compiled from a list of commercial whole house fan systems and their rated maximum airflows and power draw. The upward slope of the damper type fans suggests that the larger models have worse efficacies, whereas the slope of the propeller style fans indicates better performance for the larger models.

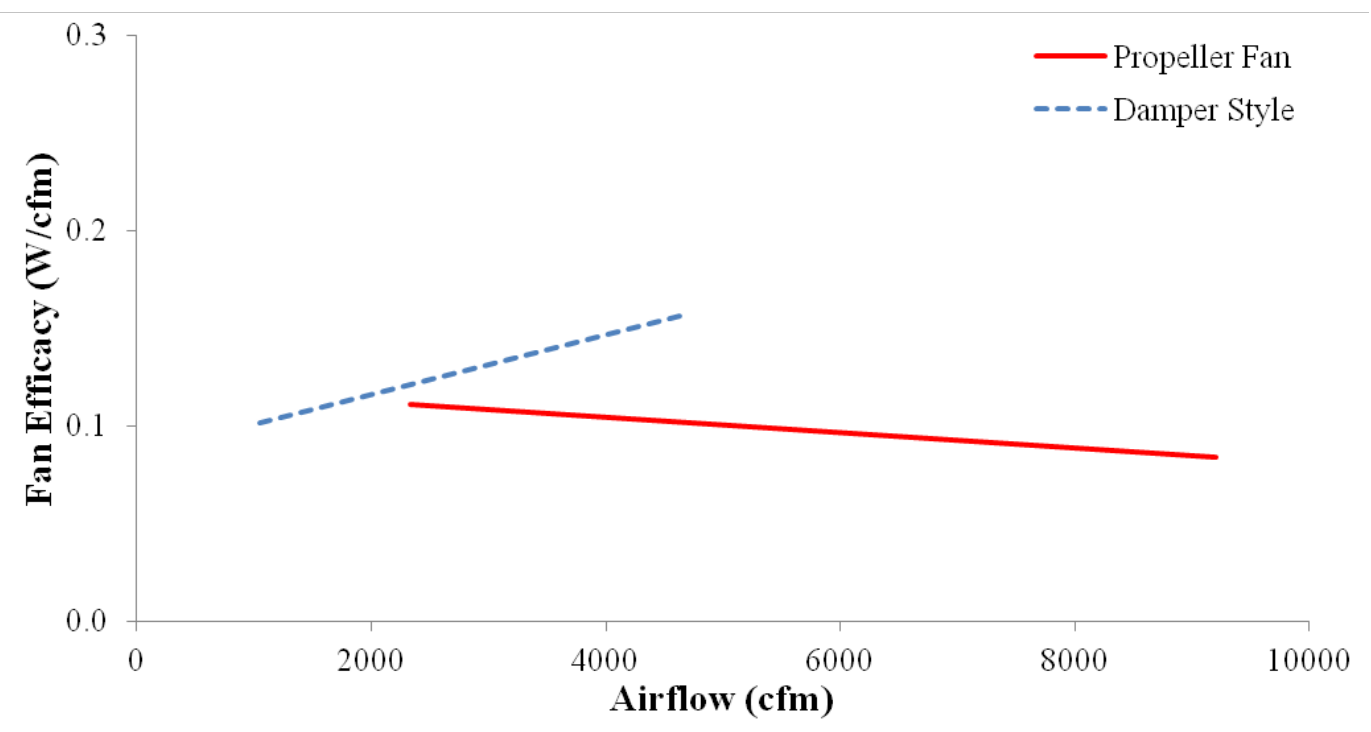

Figure 13: Typical airflow and fan power relationship for whole house fans

Variable speed fan-equipped ventilation cooling systems have the distinct advantage that they can match airflow delivery to cooling demand, and thereby operate at lower airflow rates and more favorable efficacies during mild conditions while also preventing over-cooling. Laboratory tests conducted by Davis Energy Group tested an ECM fan rated at $2000 \mathrm{cfm}$ when operating against a pressure of 0.6 ". When operating at $60 \%$ capacity, $1200 \mathrm{cfm}$, the ECM motor had an efficacy 50\% lower (better) than a hypothetical PSC motor operating under the same conditions. The baseline efficacy assumed for a PSC motor is $0.58 \mathrm{~W} / \mathrm{cfm}$ per the prescriptive requirement under California's Title-24 energy code which is based on average values from field research results in new construction homes in California (CEC, 2010). Figure 14 demonstrates how operation at lower airflows can drastically reduce ECM fan energy use.

\section{Fan Affinity Laws}

Fan affinity laws dictate that, all other things being equal, fan shaft power increases with the cube of the airflow:

$P_{1} / P_{2}=\left(Q_{1} / Q_{2}\right)^{3}$

Where $\mathrm{P}=$ shaft power and $\mathrm{Q}=$ airflow. 


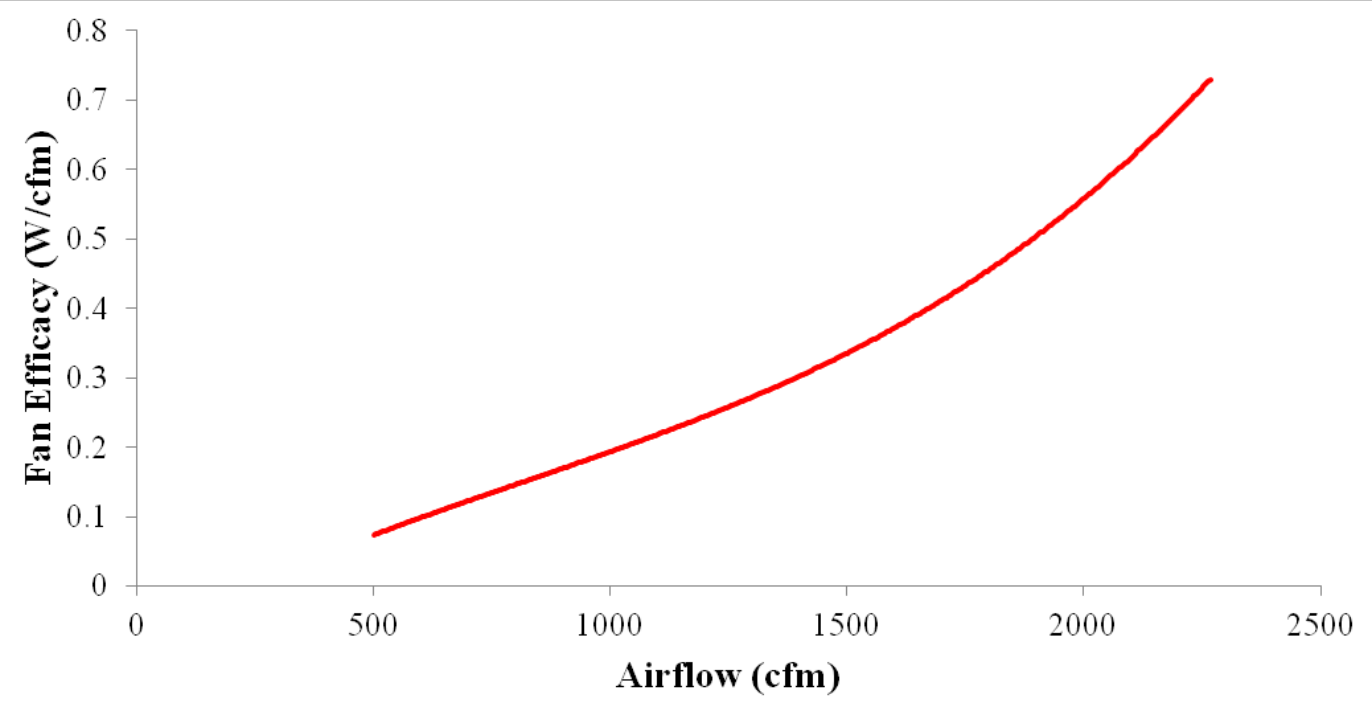

Figure 14: Fan efficacy vs. airflow for ECM fan in typical $2000 \mathrm{cfm}$ central system 


\section{Attachment C: Climate Map Details}

The climate map of the United States was developed that outlines regions with favorable climates for ventilation cooling (Figure 4). The purpose of this exercise was to provide a graphical reference only to generally identify where ventilation cooling may be justified and where it may not. The map was generated using data from the National Climatic Data Center's (NCDC) Climate Maps of the U.S. database (CLIMAPS) ${ }^{6}$, climatic parameters identified from previous research, and MATLAB simulation. The CLIMAPS site provides maps based on climate means and extremes from various NCDC weather databases. The parameters used for this analysis include mean daily temperature range, mean daily minimum temperature, and mean relative humidity. Monthly means for the month of July were used. The monthly means are computed from the daily values. Temperature data was computed using data from the National Climatic Data Center's U.S. National 1961-1990 Climate Normals (NOAA, 1994). Relative humidity data was computed using data from the National Climatic Data Center's Surface Airways Hourly (TD-3280) database (NOAA, 2000). Data obtained from CLIMAPS is grouped into geographical regions of various sizes and the resolution of these groupings is unknown.

The data from CLIMAPS was downloaded in graphical form with geographical regions color coded. The map images and color legends were then imported into MATLAB for analysis. Two filters were conducted to classify regions into four categories: 1-Minimal cooling load, space cooling is not justified; 2-Mild climates where ventilation cooling could potentially replace compressor-based cooling as the primary source of space cooling; 3-Hot climates with substantial cooling loads where diurnal temperature swings justify ventilation cooling; and 4Climates which have nighttime temperature that are too hot or humid. First, mean temperature swing and mean minimum temperature were compared and locations were classified according to Figure 15.

\footnotetext{
${ }^{6}$ http://hurricane.ncdc.noaa.gov/cgi-bin/climaps/climaps.pl?directive=welcome\&subrnum=
} 


\begin{tabular}{|c|c|c|c|c|c|c|c|c|c|}
\hline \multirow{2}{*}{$\begin{array}{c}\text { Mean Minimum } \\
\text { Temp }\end{array}$} & \multicolumn{9}{|c|}{ Mean Temperature Swing } \\
\hline & $<10$ & $10-15$ & $15-20$ & $20-25$ & $25-30$ & $30-35$ & $35-40$ & $40-45$ & $>45$ \\
\hline $25-32$ & 1 & 1 & 1 & 1 & 1 & 1 & 1 & 2 & 2 \\
\hline $32-40$ & 1 & 1 & 1 & 1 & 1 & 2 & 2 & 2 & 3 \\
\hline $40-50$ & 1 & 1 & 1 & 2 & 2 & 2 & 3 & 3 & 3 \\
\hline $50-60$ & 1 & 1 & 2 & 2 & 3 & 3 & 3 & 3 & 3 \\
\hline $60-70$ & 1 & 2 & 2 & 3 & 3 & 3 & 3 & 3 & 3 \\
\hline$>70$ & 4 & 4 & 4 & 4 & 4 & 4 & 4 & 4 & 4 \\
\hline
\end{tabular}

\begin{tabular}{|ll|}
\hline 1 & Minimal cooling load \\
2 & Possible elimination of compressor based cooling \\
3 & Potential for good cooling energy savings \\
4 & Too hot \\
\hline
\end{tabular}

Figure 15: Comparison of mean temperature swing and mean minimum temperature

Second, a filter for relative humidity was applied to these categories. Some areas previously designated at 2 or 3 were re-designated as 3 or 4 where average monthly relative humidity was above 55\%. This re-assignment can be seen in Figure 16.

\begin{tabular}{|c|c|c|c|c|c|c|c|c|c|}
\hline \multirow{2}{*}{$\begin{array}{c}\text { Mean Minimum } \\
\text { Temp }\end{array}$} & \multicolumn{9}{|c|}{ Mean Temperature Swing } \\
\hline & $<10$ & $10-15$ & $15-20$ & $20-25$ & $25-30$ & $30-35$ & $35-40$ & $40-45$ & $>45$ \\
\hline $25-32$ & 1 & 1 & 1 & 1 & 1 & 1 & 1 & 2 & 2 \\
\hline $32-40$ & 1 & 1 & 1 & 1 & 1 & 2 & 2 & 2 & 3 \\
\hline $40-50$ & 1 & 1 & 1 & 2 & 2 & 2 & 3 & 3 & 3 \\
\hline $50-60$ & 1 & 1 & 5 & 5 & 3 & 3 & 3 & 3 & 3 \\
\hline $60-70$ & 1 & 6 & 6 & 6 & 6 & 6 & 6 & 6 & 6 \\
\hline$>70$ & 4 & 4 & 4 & 4 & 4 & 4 & 4 & 4 & 4 \\
\hline IF RH & \multicolumn{6}{|c|}{ IF RH $>55 \%$; A/C necessary for dehumidification, RE-DESIGNATE as 3.} & & & \\
\hline IF RH & \multicolumn{6}{|c|}{ IF RH>55\%; Too humid, RE-DESIGNATE AS 4.} & & & \\
\hline
\end{tabular}

Figure 16: Comparison of mean temperature swing, mean minimum temperature, and relative humidity 


\section{Attachment D: Modeling Methodology and Detail}

Under earlier research, DEG developed an external function for DOE-2.1E that simulated central fan type ventilation cooling systems. Developed by LBNL, this external function cannot be used with DOE-2.2 or BEopt and is no longer supported. To estimate savings, a TRNSYS model was developed using the same functionality. The modeling evaluated the benefits of whole house fan systems as well as central ducted systems. Modeling parameters and assumptions are listed in the following tables.

The base case air conditioning energy use was determined by modeling a SEER 13 air conditioner (AC). The performance parameters were based off of the BA Benchmark House Simulation Protocols (DOE, 2010). A cooling coil using bypass fraction approach was chosen for the AC condensing unit (Type 964). Parameters and DOE-2 coefficients were gleaned from the BA Benchmark SEER 13 AC unit from BEopt version 1.1.

Table 10: SEER 13 Air Conditioner Modeling Parameters

\begin{tabular}{l|c}
\hline Parameter & Value \\
\hline \hline Nominal SEER & 13 \\
\hline EER & 11.09 \\
\hline Nominal SHR & 0.75 \\
\hline Nominal EIR & 0.25673803 \\
\hline Fan Flow (cfm/Btuh) & 0.03132 \\
\hline Fan Power $(\mathrm{W} / \mathrm{cfm})$ & 0.364 \\
\hline
\end{tabular}

The systems were modeled in a standard $2400 \mathrm{ft}^{2}$ BA Benchmark home. The house was assumed to be square, with equal wall area and equal window area for all orientations. The construction assumptions were based on the BA Benchmark House Simulation Protocols for each climate zone (DOE, 2010). A two-zone house (attic zone and living zone) was created in the preprocessor program TRNBuild. Some of the general parameters are listed below.

Table 11: General House Assumptions for TRNSYS

\begin{tabular}{l|c}
\hline Parameter & Value \\
\hline \hline Volume & $543.7 \mathrm{~m}^{3}$ \\
Capacitance & $2520.42 \mathrm{~kJ} / \mathrm{k}$ \\
Wall Area per orientation & $38.62 \mathrm{~m}^{2}$ \\
Exposed Slab Area & $44.59 \mathrm{~m}^{2}$ \\
Covered Slab Area & $178.37 \mathrm{~m}^{2}$ \\
Ceiling Area & $222.97 \mathrm{~m}^{2}$ \\
Attic Volume & $300 \mathrm{~m}^{3}$ \\
Roof Area per orientation & $58.53 \mathrm{~m}^{2}$ at $45^{\circ}$ slope \\
\hline
\end{tabular}

The insulation and window values were tailored to each climate zone based on the BA Benchmark modeling protocols (DOE, 2010). The foundation was assumed to be slab for all climate zones. Library assemblies where created in TRNBuild to replicate the BA Benchmark 
properties in BEopt. The AC capacity equipment size was estimated from BEopt simulations of the house.

Table 12: House Assumptions by Climate Zone

\begin{tabular}{c|c|c|c|c|c}
\hline Climate & Hot-Dry & Marine & Mixed-Dry & Cold & Cold \\
\hline \hline Climate Zone & CZ 3B & CZ 3C & CZ 4B & CZ 5A & CZ 6A \\
\hline Representative City & $\begin{array}{c}\text { Sacramento, } \\
\text { CA }\end{array}$ & $\begin{array}{c}\text { Santa Rosa, } \\
\text { CA }\end{array}$ & $\begin{array}{c}\text { Albuquerque, } \\
\text { NM }\end{array}$ & $\begin{array}{c}\text { Denver, CO } \\
\text { Burlington, } \\
\text { VT }\end{array}$ \\
\hline Wall Insulation & R-13 & R-13 & R-13 & R-13+R-5 & R-13+R-5 \\
\hline Window U-value/SHGC & $0.4 / 0.3$ & $0.4 / 0.3$ & $0.35 / 0.35$ & $0.35 / 0.35$ & $0.35 / 0.35$ \\
\hline Slab Insulation R-Value and Depth & 0 & 0 & $10,2 \mathrm{ft}$ & $10,2 \mathrm{ft}$ & $10,4 \mathrm{ft}$ \\
\hline Ceiling Insulation R-Value & 30 & 30 & 38 & 38 & 49 \\
\hline AC Capacity & 4 ton & 3 ton & 3 ton & 3 ton & 2 ton \\
\hline
\end{tabular}

The cooling setpoint for the house was assumed to be $76^{\circ} \mathrm{F}$ and the ventilation setpoint was $65^{\circ} \mathrm{F}$. The estimated base case annual energy use and annual utility costs ${ }^{7}$ for each climate region is presented in the table below.

Table 13: Base Case Cooling Energy Use by Climate Region

\begin{tabular}{l|c|l|c|c|c}
\hline $\begin{array}{c}\text { Building } \\
\begin{array}{c}\text { America } \\
\text { Climate Region }\end{array}\end{array}$ & $\begin{array}{c}\text { IECC } \\
\text { Climate } \\
\text { Zone }\end{array}$ & Location & $\begin{array}{c}\text { Annual Base } \\
\text { Case Cooling } \\
\text { Energy Use } \\
(\mathbf{k W h})\end{array}$ & $\begin{array}{c}\text { Annual Base } \\
\text { Case cooling } \\
\text { Fan Energy } \\
\text { Use (kWh) }\end{array}$ & $\begin{array}{c}\text { Total Annual } \\
\text { Cooling } \\
\text { Energy Use } \\
(\mathbf{k W h})\end{array}$ \\
\hline \hline Hot-Dry & 3B & Sacramento, CA & 965 & 99 & 1064 \\
\hline Marine & 3C & Santa Rosa, CA & 113 & 8 & 121 \\
\hline Mixed-Dry & 4B & Albuquerque, NM & 1113 & 136 & 1249 \\
\hline Cold & 5B & Denver, CO & 881 & 58 & 939 \\
\hline Cold & 6A & Burlington, VT & 344 & 21 & 365 \\
\hline
\end{tabular}

A whole house fan was modeled as a fixed speed fan with insulated louvers. The rated fan flow was assumed to be $1527 \mathrm{cfm}$ at $228 \mathrm{~W}$. During the cooling season ${ }^{8}$, the fan operates at night between the hours of 8:00 pm and 8:00 am when the outdoor temperature is $5^{\circ} \mathrm{F}$ cooler than the indoor temperature and the indoor temperature is above the $65^{\circ} \mathrm{F}$ ventilation setpoint.

Compressor air conditioning is assumed to operate anytime the house exceeds the $76^{\circ} \mathrm{F}$ cooling setpoint.

Variable speed central fan ventilation systems were modeled based on fan flow and fan power equations derived for the 2013 California Building Energy Efficiency Standards. ${ }^{9}$ Maximum air

\footnotetext{
${ }^{7}$ Costs are estimated based on a fixed national average rate of $\$ 0.1126$ per $\mathrm{kWh}$

${ }^{8}$ The cooling season is assumed to be between May 1 and October 31 .

${ }^{9}$ Night Ventilation Cooling Compliance Option was submitted May 2011 to the California Energy Commission for inclusion in the 2013 California Building Energy Efficiency Standards. Accessed October 2011. http://energy.ca.gov/title24/2013standards/prerulemaking/documents/2011-0531 workshop/review/2013 CASE_Res NightVentCooling_DEG 052711.pdf
} 
flow and maximum power are based on conditioned floor area (CFA). For the $2400 \mathrm{ft}^{2}$ modeled home, the maximum air flow is $1440 \mathrm{cfm}$ and the maximum fan power is 774 watts. The fan flow and fan power are adjusted based on a calculated air flow fraction (AF) which is dependent on the previous day's maximum temperature (Tmax).

The adjusted air flow fraction allows for more ventilation on hotter days and minimizes ventilation on mild days. Like the whole house fan, the night vent fan will operate any time the outdoor temperature is $5^{\circ} \mathrm{F}$ cooler than the indoor temperature and will continue until the indoor temperature reaches the $65^{\circ} \mathrm{F}$ ventilation setpoint. Air conditioning operates if the house reaches the $76^{\circ} \mathrm{F}$ cooling set point.

The fixed speed central fan system operates under the same conditions as the variable speed fan. The fixed speed fan assumes the maximum air flow and power $(\mathrm{AF}=1)$.

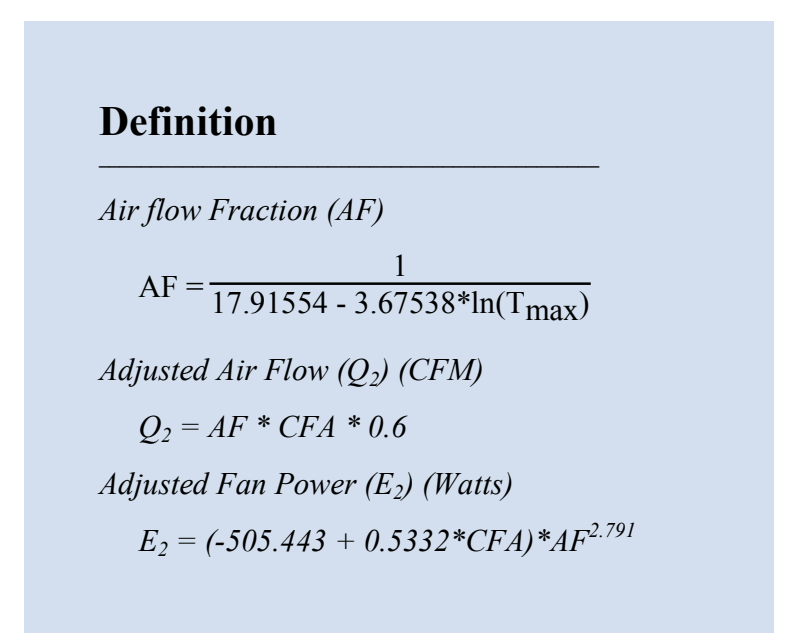

\section{Example Cost Savings}

Operating cost savings are dependent on climate, system type, house design, how the system is operated, and electric utility rates. Because ventilation cooling systems shift cooling energy use to nighttime hours, application of time-of-use (TOU) utility rate schedules will increase utility cost savings. Hourly energy use data from TRNSYS simulations were used to quantify TOU savings for a hot-dry (Sacramento) climate. The hourly data were applied to a national average fixed rate of $\$ 0.1126$ per $\mathrm{kWh}$ and to PG\&E's TOU (E-6) rate schedule, which ranges from $\$ 0.093 / \mathrm{kWh}$ off-peak to $\$ 0.445$ per kWh on-peak. Table 14 shows that for this particular case, the TOU rate schedule increased cost savings three to four-fold for the whole house fan and variable speed central systems and converted negative savings to significant positive savings for the fixed speed system type. Enhancements to building thermal mass would yield an additional increase in TOU energy savings.

Table 14: Sacramento Energy Savings and Utility Savings Based on Standard and TOU Rates

\begin{tabular}{|l|c|c|c|c|c}
\hline \multicolumn{1}{c|}{ Summary } & $\begin{array}{c}\text { Estimated } \\
\text { Cooling Energy } \\
\text { Savings } \\
\text { (kWh/season) }\end{array}$ & $\begin{array}{c}\text { Standard } \\
\text { Rate Utility } \\
\text { Savings } \\
\text { (\$/year) }\end{array}$ & $\begin{array}{c}\text { TOU Rate } \\
\text { Utility } \\
\text { Savings } \\
\text { (\$/year) }\end{array}$ & $\begin{array}{c}\text { \% Whole } \\
\text { House } \\
\text { Energy } \\
\text { Savings }\end{array}$ & $\begin{array}{c}\text { \% Whole } \\
\text { House } \\
\text { TOU Cost } \\
\text { Savings }\end{array}$ \\
\hline \hline Whole House Fan & 212 & $\$ 24$ & $\$ 89$ & $5 \%$ & $11 \%$ \\
\hline Variable Speed & 135 & $\$ 15$ & $\$ 67$ & $3 \%$ & $8 \%$ \\
\hline Fixed Speed & -1.9 & $-\$ 0.2$ & $\$ 26$ & $0 \%$ & $3 \%$
\end{tabular}




\section{References}

ACCA. Manual D Residential Duct Systems. Air Conditioning Contractors of America.

ACCA. Manual J Residential Load Calculations, Eighth Edition. Air Conditioning Contractors of America.

ACCA. Manual S Residential Equipment Selection. Air Conditioning Contractors of America.

ASHRAE (2009). 2009 ASHRAE Handbook-Fundamentals. American Society of Heating, Refrigerating and Air-Conditioning Engineers, Inc.

ASHRAE (2010). ASHRAE Standard 62.2 - 2010: Ventilation and Acceptable Indoor Air Quality in Low-Rise Residential Buildings. American Society of Heating, Refrigerating and AirConditioning Engineers, Inc.

Brynn, J. (May/June 1999) “Finding the Whole House Fan That Fits.” Home Energy Magazine.

CEC (2010). "2008 Building Energy Efficiency Standards - Residential Compliance Manual.” California Energy Commission, CEC-400-2008-016-CMF-Rev1. July, 2010.

CEC (2011). "Codes and Standards Enhancement Initiative: Night Ventilation Cooling Compliance Option". California Utilities Statewide Codes and Standards Team. Available at: http://www.energy.ca.gov/title24/2013standards/prerulemaking/documents/review/Reports/Resid ential/HVAC/2013\%20CASE\%20R\%20SEMPRA\%20Res_NightVentCooling\%202011.09.27.p df

CARB (December 2009). "2009 Annual Progress Report Budget Period 2 (BP2) - Attachment AA: Integrated Ventilation Cooling Summary Report." Prepared for the Department of Energy by The Consortium for Advanced Residential Buildings.

City of Elk Grove (2007). "Ventilation Calculation Worksheet."

http://www.docstoc.com/docs/27729071/Ventilation-Calculation-Worksheet. Accessed August 29th, 2011.

DOE (2010). "Building America House Simulation Protocols" DOE/GO-102010-3141: DOE Building Technologies Program. Department of Energy

DOE (March 1999). "Whole House Fan.” DOE/GO-10099-745: DOE Building Technologies Program. Department of Energy.

ICC (2012). 2012 International Building Code. International Code Council (ICC).

Loisos, G.; Springer, D. (2000). “Alternatives to Compressor Cooling Project Phase IV Final Report." Project report, California Energy Commission Contract No. 500-97-013. Sacramento, California. 
Matrix. (2007). "Residential Night Ventilation Monitoring and Evaluation." PG\&E Emerging Technologies Program Application Assessment Report \# PGE0710.

NOAA (1994). Monthly Normals of Temperature, Precipitation, and Degree Days for the U.S., National Climatic Data Center, Federal Building, 151 Patton Ave., Asheville, NC, 28801-5001.

NOAA (2000). Surface Airways Hourly (Data Set Documentation TD-3280), National Climatic Data Center, Federal Building, 151 Patton Ave., Asheville, NC, 28801-5001.

PG\&E (2007). "Residential Night Ventilation Monitoring and Evaluation.” Project report prepared by Matrix Energy Services for Pacific Gas \& Electric Company. Charleen Spoor, project manager. San Francisco, CA.

PG\&E. Technical Sheet - Whole House Fans. Pacific Gas \& Electric. Pacific Gas \& Electric. http://www.pge.com/includes/docs/pdfs/shared/saveenergymoney/rebates/whftechsheetv5.pdf. Accessed August 29th, 2011.

Price, P; Sherman, M. (April 2006). "Ventilation Behavior and Household Characteristics in New California Homes.” Lawrence Berkeley National Laboratory. LBNL 59620.

Springer, D. (July/August 2003). "Kicking the Air Conditioner Habit." Home Energy Magazine.

Springer, D. (2004). “Alternatives to Compressor Cooling, Phase V: Integrated Ventilation Cooling." Final project report, California Energy Commission Contract No. 500-04-009. Sacramento, California.

Springer, D; Rainer, L; Dakin, B. (2005). "Development and Testing of an Integrated Residential Night Ventilation Cooling System." ASHRAE Transactions Vol. 111, Pt. 2, 2005. American Society of Heating, Refrigeration, and Air Conditioning Engineers. Atlanta, GA.

Springer, D., G. Loisos, L.I. Rainer (2000). "Non-Compressor Cooling Alternatives for Reducing Residential Peak Load." Paper \#521, Panel 1, ACEEE Summer Study. American Council for an Energy Efficient Economy, Washington, D.C.

Springer, D. (2007). "SMUD Off-Peak Over-Cooling Project Final Report.” California Energy Commission, PIER Renewable Energy Technologies Division. CEC-500-00-034.

Wilcox, B. (2007). "Revisions to Residential Standards and ACM Calculations." Presented by Bruce Wilcox to the California Energy Commission. June 13, 2007. http://www.energy.ca.gov/title24/2008standards/prerulemaking/documents/2007-06-1315_workshop/presentations/Wilcox070613c1.pdf 


\section{U.S. DEPARTMENT OF Energy Efficiency \& ENERY Renewable Energy}

